\title{
TEXTVARIANTEN IN POLNISCHEN KANTIONALEN
}

\author{
Ein Beitrag zum evangelischen Kirchenlied in Schlesien
}

\section{Reinaldo Bossmann Universidade do Paraná}

\begin{abstract}
Die vorliegende Studie ist die Fortsetzung meiner im Jahre 1953 veröffentlichten Untersuchung über "Altere polnische Gesangbiicher in Schlesien" (Livros de cânticcs poloneses antigos na Silésia). Die Arbeit erschien in der Zeitschrift "Logos" (Revista cultural e informativa do Centro Acadêmico da Faculdade de Filosofis da Universidade do Paraná), Nr, 17, 18 u. 19, Jhrg. VIII, Curitiba, 1953, und auch als Sanderdruck, dessen Vertrieb der Universitätsverlag Carl Winters, Heidelberg, freundlicherweise übernommen hat. Als Beitrag zur Geschichte des evangelischen Kirchenliedes in Schlesien bot die Studie eine Gesamtschau über die polnischen Kantionale, mit allen bibliographischen Angaben, und eine Beschreibung dieser Art von Drucken.

Die Untersuchung uber "Textvarianten in polnischen Kantionalen" versucht, die Abhängigkeit der schlesischen Kantionale von älteren Thorner, Danziger und Königsberger Vorlagen $\mathrm{zu}$ beweisen. Die Nennung der einzelnen Drucke erfolgt auch hier - aus Gründen der Vereinfachung -- durch das gleiche System von Abkürzungen, wie es in der Abhandlung "Altere polnische Kantionale in Schlesien" angewandt wurde. Die Zahl hinter der Abkürzung bedeutet das Erscheinungsjahr der betreffenden Liedersammlung.
\end{abstract}

Schon zu Luthers Zeiten ist an den alten Gesängen viel geändert worden. Luther selbst, um seiner Kirche einen Liederschatz zu geben, änderte manchen Gesang der römisch-katholischen Kirche und formte auch weltliche Lieder $\mathrm{zu}$ frommen Zwecken um. Solche Lieder, da sie den Geist und die Reinheit der Glaubenslehre widerspiegeln, mußten zwangsläufig einer Änderung in Text und Inhalt unterliegen. Die alten Lieder der evangelischen Kirche, die in der sprachlichen Form den Stempel ihrer Entstehungszeit tragen, waren schon nach einigen Jahrzehnten späteren Generationen schwer verständlich geworden.

Mit der Fortentwicklung der Sprache, mit dem Bedeutungswandel vieler Wörter, mußjten die Lieder, da sie stets le- 
bendiges geistliches Gut der Kirche sein und bleiben sollten, Schritt halten, um nicht als unverständliche Archaismen Zweck und Aufgabe einzubüßjen. Jedes Lied atmet Sprache und Geist seiner Entstehungszeit, jede Änderung in Text und Sinn eines Liedes trägt somit das Merkmal der Zeit und Anschauung, in der und um derentwillen diese Änderung geschah.

Unzählige Lieder entstanden zu allen Zeiten. Ihr Schicksal war ein vielfältiges. Nach einer kurzen Blütezeit waren sie entweder in Vergessenheit geraten, oder aber sie gehörten nun zum fortdauernden Bestand der protestantischen Kirche. Mit der allgemeinen Verbreitung der gedruckten Gesangbücher um die Mitte des 16. Jahrhunderts war das Schicksal vieler Lieder durch ihre Einreihung oder Nichtaufnahme in sie bald entschieden. Jede größere Stadt Deutschlands war bestrebt, für ihre Gläubigen ein eigenes Gesangbuch zu schaffen. Welche Gesänge aufgenommen oder im Text erst geändert wurden, bedingten oft die örtlichen Verhältnisse, oder es war dies der Willkür der einzelnen geistlichen Herausgeber unterworfen. Die in den Liedern vorgenommenen Textänderungen und Liederweiterungen waren vielfach sinnvoll und vom Zeitgeist der Sprache bedingt, häufig aber auch unnötig und vom persönlichen Ehrgeiz der Herausgeber beeinflußt. Willkürliche Veränderungen an den Liedern hatten mitunter bei den Gläubigen große Verwirrung zur Folge.

Es entstehen Textvarianten, die sich meistens über mehrere Strophen, ja sogar über das ganze Lied hin erstrecken; ihnen ist die Daseinberechtigung abzusprechen, da sie nicht den Liederschatz bereichern, sondern nur verwirren. Bei Liedern, denen ursprünglich eine t'bersetzung zugrunde lag, und die daneben noch eine zweite erfuhren, hätte man, mindestens bei der Drucklegung, ein vorsichtigeres Verfahren anwenden, nämlich die günstigere und bessere Ubersetzung stehen lassen und die andere Ubersetzungsvariante ausmerzen sollen.

Da das geistliche Lied außer einem Dankgebet noch zur religiösen Erbauung beitragen soll, muß es vor allen Dingen immer verständlich sein und bleiben. Es unterliegt dem Wandel der Sprache. Ein Lied mit unverständlichen Worten und 
Ausdrücken kann den Sänger oder Leser nicht ansprechen. In diesem Falle hat es seinen tieferen Sinn verloren. Um das Verhältnis des Verstehens zwischen Lied und Sänger zu wahren, waren sprachliche Erneuerungen im Liede geradezu eine Bedingung. Geschahen solche Verbesserungen aus diesem Geiste heraus, so waren sie nur gutzuheißen. Dagegen jedes überflüssige und nicht bedingte Ändern am Liedtext ist als negativer Eingriff zu bewerten.

Die große Vielfarbigkeit deutscher evangelischer Kirchenlieder in den verschiedensten Gesangbüchern gilt auch für das polnische protestantische Kirchenlied, das ebenso großen Veränderungen unterworfen war.

$\mathrm{Da}$ es im hohen Maße aus dem deutschen und tschechischen Liederschatz durch Ubersetzungen geschöpft hat, sind Textvarianten in den polnischen Gesangbüchern noch häufiger anzutreffen. Die ältesten polnischen Kantionale der evangelischen Kirche weisen häufig zwei verschiedene tbersetzungsfassungen eines Liedes auf.

Auch die ersten in Schlesien gedruckten Kantionale bringen, nach den älteren Thorner, Danziger und Königsberger Vorbildern, oft nebeneinander zwei Liedvarianten. Ganz allmählich kristallisiert sich im Laufe der Zeit eine Liedfássung heraus. Die Verschiedenheiten werden ausgeglichen und gestalten in späteren Drucken einen verbindlichen Text. Die Entwicklung der polnischen Sprache hat in gleicher Weise den Liedern Änderungen und Verbesserungen aufgezwungen. Die für Schlesien gedruckten Kantionale hätten sich der hier gesprochenen Mundart bedienen müssen, damit die Gesänge überhaupt vom Volke verstanden werden konnten. Da $\beta$ man davon, außer in den von Schlesiern übersetzten Liedern, nicht reichlich Gebrauch gemacht hat, werden die folgenden Beispiele beweisen. Die Verfasser schlesischer Kantionale haben im wesentlichen die Gesänge, ohne große Veränderungen, älteren polnischen Vorlagen entnommen. Aus der Fülle der Lieder in den schlesischen Gesangbüchern können nur, um die textlichen Verschiedenheiten aufzuzeichnen, einige markante Beispiele herausgegriffen werden. $\mathrm{Da}$ außer polnischen 
Gesangbüchern Schlesiens zur Gegenüberstellung und Vergleichung noch einige polnische Thorner und Danziger wie deutsche und tschechische Liedersammlungen benutzt werden, die eine häufige Nennung erfordern, wird auch hier ein System von $\Delta$ bkürzungen angewandt werden:

KG 1646: Cantional, t. i. Pieśni Chrześćianskie; ... a teraz znowu według Torunskiey Edycyey wydane, we Gdańsku drukował Andrzey Hünefeld, 1646. 834 S., 15 ungez. Bl. $8^{\circ}$.

Stadtbibl. Breslau 8 n B 1013. Aus der Christophorikirche. Der Originaltitel des Stückes fehlt.

Er wurde von späterer Hand ergänzt.

KT 1646: Cantional, To jest Pieśńi Krześćiáńskie : ...W Toruniu Drukował Michael Carnall, M.DC. XLVI. 583 S., 63 S. 180 S. 17 ungez. Bl. $8^{\circ}$ [Vorrede unterz.:] (Artomius - 1601.)

KT 1672: Kancyonał, To jest Pjeśńi Chrześćiáńskie ku chwale Bogá w Trojcy S. Jedynego y poćieße wiernych jego : ... y z Niemieckiego przetłumáczonych; aż tez y Modlitew rożnych. W Toruniu swym Koßtem wydrukował Johannes Coepselius. Roku 1672. 945 S. 9 ungez. Bl. [Register] 235 S. $8^{\circ}$.

KT 1697 : Kancyonal to jest Pieśni y Modlitwy Chrześciańskie $\mathrm{Na}$ chwałę Boga w Trojcy S. Jedynego y ku pocieße wiernych iego W Toruniu nakładał Samuel Genter. $1697.665 \mathrm{~S} .13$ ungez. Bl. $8^{\circ}$.

Stadtbibl. Breslau : 8 N 827

Aus der Bibl. Mar. Magdalena.

KP 1915: Nowo wydany Kancyonał Pruski, ... Cum Gratia et Privil. S.R.M. Borussiae. W Królewcu Drukował ko $\beta$ tem swoim Hartung. 1915. 882 S., 64 S., 15 S., 30 ungez. Bl. $8^{\circ}$.

PD 1564: Pjsné Duchownj Ewangelistké / ... y Národ y gazyk Césky. Anno Domini 1564. $376 \mathrm{Bl} .14$ ungez. B1. $4^{\circ}$. Stadtbl. Breslau: 2 K 233. 
KBC 1828 : Kancyonal to gest Kniha żal'mu y Pjsnj duchownjch, ...w Berljné v. Fr. Späthen wytissténych. W Wratislawó k dostánj v Naklídatele Jana Frydrycha Korna, starssjho. Léta Páné 1823. 830 S., Ggg - Lll 2, 32 ungez. Bl. $8^{\circ}$.

KHM 1611 : Vollständige Kirchen $=$ und Haus $=$ Music / Darinn außerlesene Gesänge / Psalmen und Hymni, auff die gewöhnliche Sonn $=$ und Fest $=$ Tage $/ \ldots$ So mehrentheils Anno 1611. zu Görlitz in Druck außgegangen: Anjetzo aber zu de $\beta$ Allerhöchsten Lob und Ehr / auff inständiges Anhalten Christlicher Hertzen / zum Fünften mal au $\beta$ gefertiget / und mit vielen Geistreichen Gesängen / nebst ihren Melodeyen. / vermehret und gebessert. Sampt Dreyen nutzbaren Registern. Cum Gratia \& Privilegio. Breßlaw / In der Baumannischen Erben Druckerey Druckts Joh. Christoph Jacob / Factor. 1. 970 S. 25 ungez. Bl. $8^{\circ}$.

Stadtbibl. Breslau: 8 n B 970e.

GL 1618: Geistliche Lieder / D. Martin Luth. vnd anderer fromen Christen / nach Ordnung der Jarzeit / mit Collekten und Gebeten. Breßlaw / M. DCX VIII. 182 S., 2 ungez. Bl. (Vorrede und Anordnung) $8^{\circ}$.

Stadtbibl. Breslau 8 n B 966.

SG 1718: Vollkommenes Schlesisches Kirchen-GesangBuch / ... Zum 3 ten mahle aufs neue gedruckt Und mit vielen schönen Liedern vermehret. Wobey eine Vorrede Herrn Caspar Neumanns, weyland der Evangelisch. Kirchen und Schulen in Breßlau Inspectoris. Breslau und Liegnitz / Verlegts Michael Rohrlachs / seel. Wittib und Erben / An. 1718. 634 S., 12 S., ungez. Bl. $8^{\circ}$.

Stadtbibl. Breslau, Sign. 8 nB 975.

BG: Kleines Bre $\beta$ lauisches Gesangbuch / . B Bre $\beta$ law / Im der Baumannis. Erben Buch-Druckerey / druckts Joh. Jancke / Fact. 587 S. $8^{\circ}$.

Stadtbibl. Breslau: $8 \mathrm{nB} 972$. 
W: Das Deutsche Kirchenlied von Martin Luther bis auf Nicolaus Herman und Ambrosius Blaurer. Von Dr. K.E.P. Wackernagel. Stuttgart. Verlag von S.G. Liesching. 1841. 894 S. $8^{\circ}$.

M: Geistliche Lieder der Evangelischen Kirche aus dem sechzehnten Jahrhundert. Nach den ältesten Drukken herausgegeben von Dr. Julius Mützell, Professor am Königl. Joachimsthalschen Gymnasium zu Berlin. Erster Band. Berlin, Verlag von Th. Chr. Fr. Enslin 1855. 1155 S. $8^{\circ}$.

Nr. 1 “Kryste ktory ma $\beta$ w swey Mocy".

Der Verfasser dieses Pestliedes ist Joh. Herbinius.

K 1673 : “Pieśni Czasu Powietrza morowego", s. 593.

1.) Kryste ktory ma $\beta$ w swey Mocy / w $\beta$ elakie ludzkie niemocy / y sroga morowa Rana / musi ćię słuchać jak Pana.

2.) Zle nam śię dla Grzechow wodźi / umieramy starzy młodźi / karźeß nas wrźody y morem / ach! bądźźe naßym Doktorem.

3.) Strzeź nas w te Czasy niezdrowe / ući $\beta$ powietrźe morowe / odmień twą Karę surową / ćieß nas twą Dobroćią nową.

4.) Jad zjadły y Niebo mgłyste / rozpądź spraw Powietrźe czyste a 2 Miłośierdźia twojego uzdrów co jest niemocnego.

5.) Niechźe nas Mor nie morduje /. broń tego / co ćię miłuje / jesli nagle umrźeć mußę prźyjm do șiebie moje Duße. Amen.

Der Ausdruck jad (4. Str.) dürfte in Schlesien kaum bekannt gewesen sein, er bedeutet Gift, trucizna, mundartlich hat jad die Bedeutung "Hagel, der während eines starken Frostes fällt" (Vgl. Jan Karłowicz, Słownik gwar polskich, Krakau 1901, 2. Bd. S. 216). Zjadly, in Schlesien auch nicht verbreitet. Daß man später für zjadły gesetzt 
hat: ostry und srogi usw. beweist gleichfalls, da $\beta$ dieses Wort in Schlesien nicht eingebürgert war.

J. 174i : Bringt das Liad auf ¿. 457 unter "Pieśni czasu powietrza morowego" mit der Melodie: "Kto śię Pana Boga". Der Text gleicht im wesentlichen dem von $\mathrm{K} 1673$. Jedoch treten graphische Verschiedenheiten auf in den Strophen : 4.) Jad ziadły i Niebo mgliste (geläufigere Form). 5.) - iesti nagle - przyym do siebie - .

K 1761 : Auf S. 543 bei Szlak. Der Text wie in $\mathrm{K} 1673$, nur mit häufiger Kleinschreibung der Substantiva für kirchliche Ausdrücke. Die vorhergehenden schlesischen Gesangbücher hatten broń tego, co ćię miluje.

K 1773 : In dieser Ausgabe von Szlak ist das co in Str. 5 wieder vorhanden.

K 1776 : Auf S. 614 unter gleicher Uberschrift mit der Melodie: "Ach Boźe toć w tey niskości". Der Text weist keine Varianten von K 1673 auf. In Str. 2 ist dem Worte doktorem die Erklärung lekarzem beigegeben. Warum Bockshammer diese hinzufügte, ist nicht ganz einzusehen. Der Ausdruck doktor mupte dem Volke ebenso verständlich wie lekarz gewesen sein.

K 1804 : Die Pestlieder faßt Chuć unter " $W$ zarazaiących chorobach i powietrzu morowym " zusammen. Der Text weicht - mit der Melodie "Ach Boźe, toć w tey" - an keiner Stelle von K 1673 ab. Das Lied ist auf S. 668 unter $\mathrm{Nr} .792 \mathrm{zu}$ finden.

K 1861 : tbereinstimmung mit K 1776 ( S. 614 ) nur sind die Erklärungen fortgelassen. Str. 4: Jad ostry i niebo mgliste rozpądź ... Fiedler ersetzt hier zjadły durch ostry.

KP 1915 : Hier steht das Lied unter dem Titel " $W$ osobliwych potrzebach" auf S. 752 mit der Melodieangabe: "Chryste, dniu naßey". Der Text weist Aenderungen auf in den Strophen : '1.) - w swey mocy w $\beta z y s t k o$ - ludzie niemocy. Das w/elakie ist dadurch verdrängt. - 4.) Jad srogi... Die schlesischen Kantionale gebrauchten dem ge- 
genüber immer zjadły und in K 1861 ostry. - 5.) - przyimiy do siebie mą dußę. Hier ist dem kürzeren mą statt des alten moje der Vorzug gegeben, anderseits przyimiy statt das älteren przyim, was wohl der Grund zur Aenderung war.

Nr. 2. "Wszystko dobrze, co Bog czyni". "Was Gott tut, das ist wohl getan".

Der deutsche Text des Liedes stammt von Samuel Rodigast $^{2}$. Als polnischer Ubersetzer gilt Christian Rohrmann.

SG 1718: S. 501. "Von Göttl. Willen und Wohlgefallen". In eigener Melodie. Samuel Rodigast.

1. Was Gott thut / das ist wohlgetan / Es bleibt gerecht sein wille / Wie er fängt meine Sachen an / Will ich ihm halten stille / Er ist mein Gott / Der in der noth Mich wohl wei $\beta$ zu erhalten / Drum la $\beta$ ich ihn nur walten.

2. Was Gott thut / das ist wohlgetan / Er wird mich nicht betrügen / Er führet mich auf rechter bahn / Drum la $\beta$ ich mir begnügen / An seiner Huld / Und hab gedult / Fr wird mein unglück wenden / Es steht in seinen Händen.

3. Was Gott thut / Das ist wohlgetan / Er wird mich wohl bedenken / $\mathrm{Er} /$ als mein artzt und wundermann / Wird mir nicht gifft einschenken / Vor artzeney / Gott ist getreu / Drum will ich auf ihn bauen / Und seiner güte trauen.

4. Was Gott thuth / das ist wohlgethan / Er ist mein licht und leben / Der mir nichts böses gönnen kann / Ich will mich ihm ergeben / In freud und leid / Es kömnt die zeit / Da öffentlich erscheinet / Wie treulich er es meynet.

5. Was Gott thut / das ist wohlgethan / Mu $\beta$ ich den kelch gleich schmecken / Der bitter ist nach meinem wahn / La $\beta$ ich mich doch nicht schrecken \% Weil doch zuletzt Ich werd ergötzt Mit süssem trost im hertzen / Drum weichen alle schmertzen. 
6. Was Gott thut / das ist wohlgethan / Dabey will ich verbleiben / Es mag mich auff die rauhe bahn gleich noth und elend treiben / So wird mich Gott väterlich In seinem arm erhalten / Drum la $\beta$ ich ihn nur walten.

K 1741: Mit deutscher tberschrift ist das Lied auf $\mathbf{S}$. 438 unter "Pieśni o woli, i upodobaniu Boźkim” anzutreffen.

1. Wßytko dobrze co Bog czyni, bez krzywdy wola iego. Niech sprawy me iak chce mieni, nie kączę śię od niego, on Bogiem mym, ktory we złym przypad$\mathrm{ku}$ mię ratuie, niechże mną zawiaduie.

2. Wßytko dobrze, co Bog czyni, wiem źe mie nie zawiedzie on mym nogam Tor namieni, niewiem o żadney biedźie, $z$ tey skłoności w ćierpliwości niefiszęśćie me zkieruje, bo Swiat rękach piastuje.

3. Wßytko dobrze co Bog czyni, on mnie będzie pilnował, a nie iako Lekarz leni, iadza leki gotował, Pan to wierny, Bog niezmierny, na nim całe przestaię, i iemu się oddaię.

4. Wßytko dobrze co Bog czyni, on żywot, światłość moia, ktory dobre w złe nie zmieni, Pod nim pragnę pokoia, lub radośći, lub w tesknośći : Okaże czas na iawie że $\beta$ czerze mieni prawie.

5. Wßytko dobrze co Bog czyni, by mi Czaße zkoßtować, ktora myśl w gorzkość odmieni, nie dam śię strachom psować, bo ufanie po odmianie w Sercu pomoc cukruie, a przykrość ustępuie.

6. Wßytko dobrze co Bog czyni, przy tym pragnę zostawać, choćby mi iść w nędzney ćieni, i w przychodach ustawać, Pan w ućisku po oycowsku w rękach mię będzie chował: przeczźebym śię frasował.

In der 3. Strophe muß es richtiger "iad za leki" heiBen - " gifft vor artzeney" weist der deutsche Text auf und offenbart die umständliche, wörtliche tbersetzung ins Polnische, die dem ganzen Liede etwas Schwerfälliges gibt.

Der polnische Text ist als tbersetzung eine getreue Wiedergabe des deutschen. Wenn der tbersetzer von der deutschen Vorlage abwich, so nur um des Reimes willen. 
Zu Str. 1: Es bleibt gerecht sein. Wille - bez krzywdy wola iego. Der tbersetzer bedient sich hier des bez krzywdy für gerccht. Nie łączę śię od niego - vill ich ihm halten stille. Im Text kączę als Druckfehler für lączę. Das deutsche Not ist mit zły przyoadek wiedergegeben. Ratować hier = erhalten, zawiadowac als Ubersetzung von walten. Zu Str. 2 : "er wird mich nicht betrügen" - wiem że mnie nie zawiedzie. Mit dem poln. zawiedzie für betrügen ist eine Abschwächung der Bedeutung des Wortes erzielt. Die 2. Strophe ist frei übersetzt. doch bleibt der Sinn der deutschen Vorlage erhalten. Zu Str. 3: wohl bedenken durch pilnować übersetzt; artzt in wörtlicher tbersetzung durch lekarz, artzeney mit leki übersetzt; " na nim całe przestaie " — drum will ich auf ihn bauen; " $\mathrm{i}$ iemu się oddaię" - und seiner güte trauen. Zu Str. 4: Die Utbersetzung gibt nicht ganz den deutschen Sinn wieder: "der mir nichts böses gönen kan" ktory dobre w złe nie zmieni ". Zu Str. 5: Der Sinn der deutschen Strophe ist hier umschrieben. Es fehlt die wörtliche Ubersetzung von kelch, wahn und trost. Zu Str. 6 : Ziemlich wörtliche Ubersetzung des deutschen Verses: zostawać $=$ verbleiben. Der deutsche Text ist hier sehr frei und sehr unpoetisch ausgedrückt. Der polnische Text gibt die Hingabe in den Willen Gottes stärker zum Ausdruck. Arm durch den Plural im Lokativ mit w rękach übersetzt.

K 1761 : Jerzy Szlak, der Herausgeber dieses Kantionals bringt den Gesang auf S. 524 mit der gleichen Liedanordnung und deutschem Anfanggstext. Str. 1: - iak chce mieni, nie tączę śię od niego ( Druckfehler beseitigt, da vorher - kączę -).

K 1776 : S. 590 "O woli, i upodobaniu Bożką. Pros. 3." Bei Bockshammer wird auch der deutsche Liedanfang angegeben. Str. 1: Wßytko dobrze, co Bog czyni, bez winy wola lego ... Die vorhergehenden Texte wiesen immer bez krzywdy wola iego auf. Str. 2: - on mym nogam tor namieni, który do $\beta$ częśścia wiedzie. Więc dusliwie i cierpliwie czekam iego pomocy; on wßystko ma w swey mocy. Diese Fassung weicht von $\mathrm{X} 1741$ gänzlich ab. Str. 3: - on moy 
lekarz nie bedziemy iadu w lekach gotowal; Pan to wierny, miłośierny, na nim cale przestaie, i iemu się oddaię.

Str. 4 : - on iest moią światlością, on mi na drodze mey świeci, i prowadzi mądrością. Jak w radości tak w żałości on w $\beta$ ystko, ufam Jemu obroci ku dobremu. Str. 5 : - ktora iest pełna gorzkości, nie dam się strachom psować, bo ufanie, że nastanie wnet słodkość po gorzkości, odpędza w we przykrości. Str. 6: - przy tey wierze zostawam, a od niey i nawet śmierci odrazić się nie dawam : bo mię wß̧ędzie moy Bog będzie iak Oyciec opatrowal.

K 1790 : tberschrift und Anordnung wie in $K 1776, s$. 590. Str. 2:- on mym nagom tor namieni (Druckfehler). Str. 3: - on moy nie-będzie mi iadu w lekach gotował.

K 1804: Mit den ganzen Text begleitenden Abweichungen ist das Lied auf S. 415 in den Gesängen "O spoleganiu i spolewaniu na woli Bożey" abgedruckt. Str. 1 : - dobra iest wola iego. Niech co chce ze mną uczyni, nań czekam, ufam w niego. On Bogiem mym, który w złym przypadku mię ratuie niech daley zawiaduie. Str. 2: Wßystko dobrze, co Bog czyni, nie da padnąć mey nodze. On mą ścießę prostą czyni wiedzie mię po swey drodze. On stwierdźa mię tym cießę się, da koniec moiey biedie, on mie swą ręką wiedzie. Str. 3 : - on wie, co się nam godzi. Kto się nim nie wsparł, zawini, błędną się myślą zawodzi. Dnia każdego, nowa iego łaska; w nim ufność kładę, znam dobrą jego radę. Str. 4 : - on swiatło życia mego, nic mi złego nie uczyni, stań się

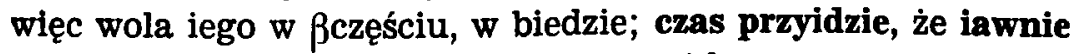
uzna każdy, iz mię wiodł wiernie zawżdy.

Zu Gunsten des deutschen Textes hat Chuć die Strophe stark geändert : czas przyidzie = es kömmt die Zeit; że iawne uzna każdy = da öffentlich erscheinet; iż mię wiodł wiernie zawżdy $=$ wie treulich er es meinet. Str. $5:-$ chociaż gorzki podaie kielich mi, zle nie uczyni, przestra $\beta y c ́$ się nie daię; doznam potym ia $w$ sercu mym pociechy iego słodkiey, po mey przykrości krotkiey.

Auch diese Strophe verrät deutlich die Aenderungen nach der deutschen tbersetzungsvorlage. Durch die enge Anklam- 
merung an den deutschen Text büßte das Polnische viel an Sprachlebendigkeit ein. Str. 6: - przytem zawße zostaię ( Dahin will ich verbleiben). Niech mą drogę przykrą czyni strach, śmierć, bieda; podaie Bog ręce swe mi oycowskie, i tak mię utrzymuie; niech daley zawiaduie ( So wird doch mich Gott väterlich in seinem arm erhalten ).

K 1861 : S. 590 "O woli, i upodobaniu Boskiem. Pros. 3 ". Mit kleinen Verbesserungen ist der Text von K 1776 beibehalten. Str. 1: - niech sprawy me, jak chce mieni, nie uciekam od niego; - mię ratuje, niech dalej zawiaduje (wie K 1804 ). Str. 2 : - on mym nogóm tor uczyni. K 1776 hat: on mym nogam tor namieni. Str. 5: Wßystko dobrze, co Bóg czyni, miałbym kielich skoßtować, który jest pełny gorzkości nie będę się frasować. K 1804 hat gleichfalls kielich.

Fiedler hat die Aenderungen unter Benutzung von K 1804 vorgenommen.

PD 1706 : Als Nr. 9 ist das Lied hier zum ersten Mal im Druck anzutreffen. Da es im Text einige Varianten aufzuweisen hat, ist diese Form in PD 1706 als die ursprünglichere anzusehen. Als Rohrmann es später seinem Kantional einverleiben wollte, nahm er noch einige Aenderungen darin vor, die dann in $\mathrm{K} 1741$ anzutreffen sind. Str. 2: - w cierpliwości Nieß̧cźęście mię z kieruie Bo swiat wrękach piastuie. Str. 3 : - On jako lekarz nie leni Jad za lek nie obaczy : -Na nim cale przestaję z jemu śię poddaje. Str. 4: - Pod nim ßukam pokoija / Lub wradości. Str. 5 : - Po odmianie Bo ufanie / Pomoc wsercu cukruje / . Str. 6: By mi się jąć smierći Sieni - Po oycowsku Wrękach mię będzie chawal.

Im Pitschener Manuskript kommt dasselbe Lied auf S. 81 vor. Der Schreiber der Pitschener Handschrift mu $\beta$ es den Breslauer Pieśni von 1706 entnommen und mit einigen Veränderungen seinem handschriftlichen Kantional beigegeben haben. Im Verhältnis zu PD 1706 kommen im Liede dieser Handschrift folgende Wortschwankungen vor:

Str. 1): - niech sprawy, nie iak chce, - we złym przypadku mnie ratuie. Str. 2: - wiem że mnie za wiedzie. 
Str. 3 : - Pod nim ßuką pokoia - Str. $5:$ - by mi cźas źe $\beta$ ko $\beta$ tował, ktoram - nie dam się strachem psować -.

KP 1915 : Aus diesem Kantional sei, um zu zeigen, welchen Aenderungen das Lied in neuerer Zeit noch unterlag, der Text des Liedes angeführt. S. 507 (mit deutscher tberschrift unter) "O taiemnicach krzyźa".

Str. 1: W/ystko dobrze, co Bog czyni, bez winy wola iego; niech sprawy me, iak chce mieni podkug rządu swoiego. On Bogiem mym, który w złym przypadku mię ratuie, niech daley zawiaduie. Str. 2: - on bez fałpu zostale, on moie trudność odmieni! on nogom tor daie! Ja zostawam, gdy tylko mam łaskę iego $\mathrm{w}$ swey biedzie, on $\mathrm{w}$ niwczym nie zawiedzie. Str. 3 : on mie $\mathrm{w}$ wßem ratuie, nie iak Lekarz więc się leni, nie iad, lecz miod gotuie : Pan to wierny, miłosierny, w nim ia mam ufność swioę, niczego się nie boię. Str. 4:- kto przy nim w prawey wierze, temu słowa swoie spełni, nie omyli $w$ tey mierze : On $w$ radości, on $w$ żałosci wiernym się pokazuie, i $\beta$ czerze się sprawuie. Str. 5 : - choćbym gorzki kielich pił, ten mi w słodkość sam odmieni, a choćby mię i zabił. To karanie, iak me zdanie, pociechami cukruie, i boleści uymuie. Str. 6: Wßystko dobrze, co Bog czyni, przy tym zaw $\beta$ e zostawem, żle myślić nie mam przyczyny, w opiekę się mu dawam. Na w/3ech drogach, i w przygodach, kto się tylko nań spuści tego on opuści.

KBC 1823: Zum Vergleich das Lied aus dem tschechischen Kantional. S. 558 "O celém odewzdáni srdce P. Geźjssj".

O Némecké : Was Gott thut, das ist wohl gethan.

Str. 1: Wsse gest dobré co Buh ćinj, prawá gest geho wule. Necht' on koná me r'jzenj, chce gemu drźet' mile : Buh Ochrańce, muź kdy on chce, $\mathrm{z}$ kr'jźe mne wytrhnauti, nechám geg panowati.

Str. 2: Wsse gest dobré co Buh ćinj, nikoli mne nezklamá. Pr'jmau cestau mne wést mjnj, pr'estáwá w tom żádost má : W geho cht'enj, mám strpenj, on zménj mé nesstéstj w rukau geho gsem gisty' 
Str. 3: Wsse gest dobré co Buh ćinj, on mug źiwot a Swétlo. W nićemź semnau zle nemjnj, gemu se dám celého: W sst'essj w smutku, pr'igde w skutku, ćas w némź toho poznáme, źe z námi mjnil' wérné.

Str. 4: Wsse gest dobré co Buh ćinj, na mne se rozpomene. On gest Lékar' $\mathrm{k}$ spomoźnj, nedá mi ged w bdé mé : W swém lećnj, gest Buh wérny', gát' w ném budu stawéti, w milost' geho daufati.

Str. 5: Wsse gest dobré co Buh ćinj, mámli ten kalich jsti, Genź gest vstum my'm odporny', nedám se pr'edesyti : Neb pr'i koncy, mému srdcy, nalege potéssenj; odstaupj wsse sauźenj.

Str. 6: Wsse gest dobré co Buh ćinj, pr'i tom zustanu stály'. Byt' mne na cestu sauźenj, bjda smrt psota hnały: Neb mne pr'edce, Buh Ochrańce, z swé ruky newypustj; nechám se genu wésti. Amen.

Die tschechische tbersetzung ist dem deutschen Text angeglichen. Der tbersetzer hat sich meist einer genauen Wiedergabe der deutschen Worte in der tbersetzung bedient. $\mathrm{Da}$, wo eine wortgetreue tbersetzung wegen des tchechischen Reimes nicht möglich war, hat der tbersetzer dennoch den Sinn getroffen. Die Anordnung der Strophen 3 und 4 ist tm Tschechischen eine vom Deutschen verschiedene. Die 7 . strophe des Tschechischen entspricht der 4. Strophe des deutschen Liedes.

\section{Nr. 3 “Przybliźa się Dźień Sądowy”. "Es ist gewißblich an der Zeit".}

Der deutsche Liedtext stammt in verbesserter Form von Bartholomäus Ringwaldt ${ }^{3}$, der ihn wahrscheinlich vor 1582 geschrieben hat. Dem Liede liegt die Sequenz "Dies irae, dies illa" zugrunde4. Das Lied wurde kurz vor 1673 von Johannes Herbinius ins Polnische übersetzt.

K 1673: S. 1034 "Przydatek Pieśni i Psalmow". "O Sądnym Dniu ". 
1.) Prźybliźa się Dźień sądowy / a z nim do nas Syn Boźy / sądźić wßßystek swiat (K 1773 S. 341 hat swiąt) gotowy / tym chwałę swą rozmnoźy / gdy złym na postrach ośiędźie Majestat / gdy w(jelkie będzie Ogniem topił źywioły. 2.) Glos Trąby (traby als Druc'xfehler in K 1773) vzbudźi krzykliwy / wßystkie Końcżyny źiemie : na ktorey okrźyk straßliwy spowstanie ludzkie plemie (plemię in $\mathrm{K} 1761 \mathrm{~S}$. 349) a tych co źywi zostaną Swiętną (K 1761: świętą) Pan Jezus prźemianą w okamgńieniu odnowi. 3.) Potym skoro z Kśiąg pisanych czytać będą na jawi co kto czynił: tam $z$ wezwanych Stary z Młodym śię sprawi / $\mathrm{z}$ lat y Poźyćia swojego / bo mu wßystkie dźieła jego na oko Bóg pokaźe. 4.) Biada temu ktory Pańskim śmiele (śmiełe in $\mathrm{K}$ 1761) pogardził słowem : a p६dem idąc Sźatańskim Marnośći pasł obłowem Dußę / Bogactwo zbierając / ten zajiste w Piekle mając byt naznaczony / zginie. 5.) Ratuy w ten cźas sługę swego / dla męki Jezu! twojey więc w Kśięgach zyćia wiecźnego day miejsce Dußy mojey / boćem ufnośćią nie zbłądźił żeś ty sam Diabła osądźił / a Dług moy Krwią zapłaćił. 6.) Oręduy za mnie Panie gdy śię objawić racży $\beta$ / a gdy mey Braći mießkanie w górnym Niebie naznacźy / chciejźe mię zarowno z nimi z Kśiąg cźytać twych / bysmy twymi wßyscy społecźnie byli. 7.) 0 Jezu prźecźźe się zwłacza 5 Dźień sąduy (Druckfehler für sądny) ostateczny Ledwie cźłowiek nierozpacza od Strachu niebezpieczny. Prźydźźe : o prźydź! Sędźio wielki! pozbaw nas Niewoli wßelkiej / day Wolność wiecźną! Amen.

K 1776 : S. 378 - Strophe 2 : - co żywi zostaną, dziwną - statt des swiętną in K 1673. Str. $3:-\mathrm{z}$ ksiąg pisanych. 6 Str.7 : - od strachu niebezpieczuy - Druckfehler für niebezpieczny.

K 1790 : S. 378.

Str. 2: - powstanie ludzkie plemie - Str. 6:w $\beta$ yscy spoleczne byli - . Hier mu $\beta$ es richtiger społecznie heißen.

K 1804 : Bei Chuć ist das Lied auf S. 268 als Nr. 308 bis zur 6. Strophe ohne Aenderungen wie in $\mathrm{K} 1673$ aufgezeichnet. Die 7. Strophe weist bei ihm eine stärkere Ab- 
weichung auf : O Jezu ! ießcze się zwłacza dzień sądny ostateczny, ale czlek niech niezabacza tego, będąc bezpieczny. Przydź w czas Boży, Sędzio wielki pozbaw nas niewoli wßelkiey, day wolność wieczną! Amen.

K 1861 : S. 378. Text wie im Bockschammerschen Kantional unter Fortlassung der Erläuterungen. Str. $1:$-; tem chwałę - in K 1673 tym. Str. 2: Wzbudzi trąby głos krzykliwy - während K 1673 "Głos trąby wzbudźi krźykliwey" hat.

Eine andere Fassung besitzt das Lied in den Thorner Kantionalen. Zuerst kommt es im Thorner Kantional von 1672 vor. Im Anhang ist es in KT 1697 auf. S. 640 unter den "Pieśni Nowotne $z$ Niemieckiego na Polski język przethumaczone" zu finden. Mit deutscher tberschrift versehen, hat es unter der Rubrik "O sądzie ostatecznym " nachstehenden Text :

1.) Juź śię cżasy przybliźyły / przyśćia Syna Bożego: Ktory wchwałe swojej śiły / okrąg świata całe Sprawiedliwie sądzić będzie tam trwoga powstanie wß̨̨dźie / gdy swiat przez ogien zgorze.

2.) Jak trą̧by głos okrzykliwy / zabrzmi na Wßystkie strony : Każdy przed sąd sprawiedliwy / z grobu wyprowadzony / stawion będzie lecż co żywych Pan znajdźie / ći wnieśmiertelnych Wnet będą przemienieni.

3.) Księgi będą tworźone / w ktorych będą cżytali : W/ystkie grzechy popelnione / tak wilecy jak i mali. Tam każdy usły $\beta y$ snadnie / co za dekret nad nim padnie / czy śmierći czy żywota.

4.) O biada $\beta$ tym wten cżaśs będźie / co na Boga niedbale: Lecż ustawicznie y wßędźie z złym światem przestawali, Ci od Pana oddaleni / na wiecżnie będa wyrzuceni Męki / wprzepaść piekielną.

5.) O Jezu racz ty przy mnie stać / przez krwawe rany twoje: A w Księgi źywota wpisać racż imię moje: nie dawaj mię na zginienie / boś ty sam moje zbawienie tyś ßatana osądźił. 
6.) Bądź ty nam orędownikiem / kiedy przed sądem stanę: Swiadcż żem ja twym hołdownikiem, niech się przy twych zostanę / Coś je wpisał w Księgi swoje: przyznaj mi dźiedzicwo9 moje / ktorys wiernym zgotowal.

7.) Jezu / przeczże tak nie spießno Odwłacż aß zprzysćiem twojim? Jużci wiernym dla bied teskno / po tobie Panu swojim. Przydź Jezu / przydź sędźio wielki / niech cię obacży człek wßßelki / zbaw nas od złego / Amen.

Durchgreifende Aenderungen offenbart die Liedform in neuerer Zeit, in KP 1915: "O przyiściu Chrystusowym"; mit deutschem Anfangstext auf S. 17:

1.) Juź zaprawdę o tym czasie, że Syn Boży k' nam przyidzie w sławnym swoim Maiestacie, a ludzkie sądzić będzie: Tam złym nie będzie do śmiechu, gdy w $\beta y$ stko zaginie w ogniu, iako Piotr o tem piße.

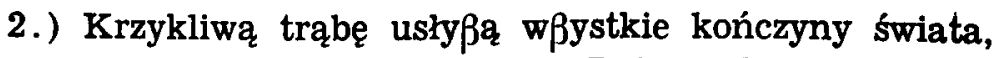
umarli ludzie powstaną na Boży rozkaz z prędka; i śmierć się też sama zlęknie, gdy usły $\beta y$ tę nowinę, źe wßyscy ludzie źyią.

3.) Księgi będą przeczytane, w ktorych iest napisano, że Bog młode i też stare będzie sądził nie tayno: Tam się każdemu dostanie, za to, co czynił bezprawie 10 po w $\beta y$ stkie lata swoie!

4. ) Pomoż ty, Troyco chwalebna! by imię moie było $w$ księgach wiecznego żywota, czasu rozstania mego: Nie odstępuy ty mnie, Chryste! bądź moy Pomoćnik zaiste, nie opußczay nędznego.

5.) A coż ia ubogi człowiek przed twoim sądem rzekę ? Ktoż będzie moy orędownik? Kto wywiedzie mą sprawę? Ty się sam tego podeymie $\beta$, ktory na ten świat przyßedłeś, abyś nas wß̧stkich zbawił.

6.) Gdy pomnę na grzechy moie, oczy się zalewaią: Gdy zaś na radości twoie, wnętrzności się raduią. O Jezu! 
przyidź mi na pomoc, bym obaczył twoie możność, w wiecznym żywocie twoim.

7.) Toć idzie $\beta$, Panie! nie spie $\beta$ no, dałeś złych dni doczekać, iuż też nam na ziemi tęskno, iednak nie day rozpaczać: Ześliy nam Ducha Swiętego, w wiedź do żywota wiecznego, ty przez siebie samego.

Nr. 4 "Wesoło śpiewajmy, Boga Ojca chwalmy."

"Menschenkind, merck eben".11

Der Autor des Liedes ist Michael Weiße, der es aus den böhmischen Brüdergesängen ins Deutsche übersetzte:

W: S. 257. Aue Hierarchia.

1.) Menschen kind, merck eben, was da sey dein leben! warumb Gott seinen Son gesandt vom höchsten thron, hat lassen mensch werden hie auff dieser Erden.

2.) Nemlich, das er leret, dich zu sich bekehret, für deine schuld stürbe, dir genad erwürbe, dich vor Gott vertrette vnd stetz für dich bete.

3.) Vnd das er durch sein geyst, den er einn tröster heyst, vnd durch sein wort kommen dir zu trost vnd frommen, möcht in deinem hertzen wonen one schmertzen.

4.) Ey, gibt stat diesem geyst, vnd thu was dich Gott heyst, öffne des hertzens pfort, das Christus durch sein Wort in dich möge kommen vnd stets in dir wonen. 
5.) Alp dann sich gar eben, das du dich ergeben in gottselig leben, jm nicht wider streben, sonder seinen willen allzeyt wirst erfüllen.

6.) Seine lieb beweysen, mit der that jn preysen, stetz in allen sachen munter sein vnd wachen, das $\mathrm{du} \mathrm{jm}$ in allem möchtest wolgefallen.

7.) Wirst du dich recht halten, so wird er dein walten, dich lassen geniessen fridsamer gewissen, dir auch zeugnü $\beta$ geben zum ewigen leben.

8.) Yetzt must du vil leyden, deinem willen meyden, vnd auff allen seyten mit dem Sathan streyten, doch es wirdt dir wolgehn, so du di $\beta$ wirst außstehn.

9.) Denn der Herre wird dir durch den Tod kommen schier, deine seel abscheyden zur ewigen freuden, bi $\beta$ die posaun angeht vnd alles fleysch auffsteht.

10.) Denn wird er leybhefftig, sehr herrlich vnd krefftig von dem Himmel steygen, reden vnd nicht schweygen, Dir vnd allen sagen, die jetzt sein joch tragen: 
11.) Kompt, jr benedeyten, zu der rechten seyten! kompt, jr außerkornen, in mir newgebornen, in meines Vaternreich, langest fertig für euch!

12.) Als denn wirstu fro sein vnd ledig aller pein, im verklertem leben mit dem Herren schweben, voller freud vnd wonne, leuchten wie die Sonne.

13.) Wol nun dem, den Gott zeucht vnd durch seinn geyst erleucht, das er Christus annimbt, wenn er durch sein wort kömbt, vnd bey jm fley $\beta$ thuth, denn seine sach ist gut.

14.) Wer aber nichts achtet, nach Christo nicht trachtet, sein hie zu geniessen, $\operatorname{der}$ sol $\operatorname{di} \beta$ mal wissen, das ers dort wird müssen in der Hellen büssen.

15.) O komm, Herre Jhesu, schick dein armes volck zu, $\mathrm{dz}$ es deinn willen thu, darnach in deiner rhu lobe deinen Namen in ewigkeyt, Amen ${ }^{12}$ ).

Im Polnischen besitzt dieses Weißesche Lied mit dem gleichen Anfangstext "Wesoło śpiewajmy " zwei unterschiedliche Fassungen. "Das polnische wie das deutsche Lied hat 15 Str., aber das poln. behandelt die vierfache Ankunft Christi gesondert, die das deutsche nur berührt ${ }^{13}$. 
KD 1646 : S. 5 f. "Pieśni Na Adwent".

1.) Wesoło spiewaymy / Boga Oyca chwalmy / źe nam Syna swego / jednorodzonego / dał na Wykupienie / prze ludzkie Zbawienie.

2.) O Przyściu Chrystusowym / czworo Pismo onim: Pierwße w swoim ćiele: Drugie jest w nas cale: Trzećie przy Skonaniu: Czwarte ku Sądzeniu.

3.) Pierw/ße Przyśćie jego / jest przodkiem dla tego / by Poselstwo sprawił / Wesele nam zjawił / ku Pokućie wołał / wiele ich vzdrawiał.

4.) Tak mowiąc vczył sam / Przykład moy daję wam / Tak jakom ja czynił / zem Zakon wypełnił / takze y wy czyńćie / Wolą Oyca pehŕcie.

5.) Wolą Oyca konał / Grzeßnych ksobie wołał / Proroctwa nie wzrußył / (K 1673 S. 10" wzrußał") bowiem ćierpieć musił / (K 1673 musial) tak swoy Lud wykupił / Piekło w/3ytko złupił.

6.) Wtore Przyśćie jego / w Myśl Serca ludzkiego przez swe swięte Słowo / wchodźi do Grzeßnego / co Pokutę czyni / jego Słowu wierzy.

7.) O ytm sam powiedźiał / y Objetnicę dał / gdźie Się w Nauce mey / zeydą dwa albo trzy / jam jest miedzy nimi / przebywając z nimi.

8.) Nie opußcżając ich / do mnie wyłających / (P 1670 S. 2 : wołaiącich als Druckfehler) ale chcę być z nimi / kazdey jich Godźiny / wßego Vdręczenia / aze do Skonania.

9.) Trzećie Przyśćie jego / do Smierći kazdego: przetoz nam czuć kazał / Obzarstwa zakazał / bowiem niewie Człowiek / w ktory Smierć przydźie Wiek.

10.) Przetoz się waruymy / a nie obćiązaymy / Serc na$\beta y c h$ Obzarstwem / ani tez Pijanstwem / Rosko $\beta y$ przestańmy / Pana w tym słuchajmy. 
11.) Cźwarte Przyśćie będźie / gdy ku Sądu siędźie / tam będzie dźiwny Dźień / gdy wstániem z Grobów weń / tamby śię rad zły skrył / by przed Panem nie był.

12.) Wßyscy Anjołowie / Chrystowi Posłowie / na Sąd z Panem przyida / wielkie Cuda będą / niz na Sądźie / źiemia śię trząść (P 1670 S. 3 : trzęść / będźie.

13.) Dźień tym straßnny będźie Dźień Smętku y Nędze / co śię Pana przeli / za nim iść nie chćieli / Swiatu w tym folgując / Ludźi naśladując.

14.) Przetoz śię przyprawy / wßech Złośći przestańmy / tak Pana czekaymy / na Modlitwach trwaymy / y w Pokutowaniu / w świętym Obcowaniu.

15.) Raczze sprawić Panie / w nas Pokutowanie / zebybysmy tak zyli / a ćiebie widźieli / Pana laskawego / na Dźień Prźyśćia twego.

$P 1760$ hat die Fassung von KD 1646, doch besteht das Lied in $P 1670$ aus nur 14 Strophen. Die 14. Strophe der Fassung von KD 1646 fehlt hier ganz. Die Fassung von $\mathrm{KD} 1646$ tritt in den schlesischen. Kantionalen an 2. Stelle als "In $\beta a$ Edycya " oder "Według starey edycey" auf. Die Gesangbücher, bis zum Jahre 1761, enthalten zwei Fassungen dieses Liedes. Die späteren Gesangbuchauflagen verzeichnen nur eine Liedfassung und zwar die neuere, wie sie das Thorner Kantional vom Jahre 1646 bietet.

KT 1646: S. 7 f. "Pieśni Na Adwent":

1.) Wesoło spiewajmy / Boga Ojca chwalmy / że on Syna swego / jednorodzonego / dał na wykupienie / prze ludzkie zbawienie.

2.) O przyśćiu Krystowym / (K 1790, S. 81 und $K$ 1804 S. 60 : Chrystusowym) swiadcży Pismo o nim: Pierwße że jest wćiele / a drugie w nas cale / Trzećie przy skonaniu / Cżwarte ku sqdzeniu.

3.) Pierwße przyśćie jego / jest przednie dla tego / by poselstwo sprawił / wesele nam zjawił: Do pokuty wołal / Wiele ich vzdrawiał. 
4.) Tak mowiąc ucżył sam / przykład moj daję wam : tak jakom ja cżynił / żem Zakon wypehnił także y wy cżyńćie / wolą Ojca pehńcie.

5.) Wolą Ojca swego / cżyniąc dla grzeßnego / Proroctwa nie wzrußjal / Bowiem ćierpieć muśiał / tak swoj lud wykupił / Piekło w $\beta y s t k o$ złupił.

6.) Wtore prżyśćie jego / do serca ludzkiego / przez Ducha świętego / wchodząc do grzeßnego / Co pokutę cżini jego wola petni.

7.) O tym sam powiedźiał / y obietnicę dał / gdźie się z nauki mey / zejdą dwa albo trzej / jam jest miedźy nimi / przebywając z nimi.

8. )' Nieopußcżając ich / do mnie wołających / ale chcę bydź znimi / każdey ich godźiny / wßego vdręczenia / aż y do skonania.

9.) Trzećie przyśćie jego / do śmierći każdego przetoż nam cżuć kazał / Obżarstwa zakazał bowiem niewie człowiek / gdy zejdźie jego wiek.

10.) Przetoż się starajmy / a nie obćiążajmy / serc na$\beta y c h$ obżarstwem / ani teź pijaństwem / roskoßy niechajmy / Pana wtym słuchajmy.

11.) Cżwarte przyśćie będźie / gdy na sąd zaśiędźie / tam będźie dźień dźiwny / niezbożnym przećiwny / tamby się rad zły skrył / by prżed Panem nie był.

12.) Wßyscy Anjołowie / niebiescy posłowie / na sąd z Panem przydą / wielkie cuda będą / niż na sądźie siędźie / źiemia śię trząść będźie.

13.) Dźień tym straßny będźie / dźień smętku y nędze / co się Pana przeli / za nim isćc niechćieli / swiatu pochlebując / ludźi naśladując ${ }^{14}$.

14.) Dla tego powstańmy w/3ech złośći przestańmy / tak Pana czekajmy / na modlitwach trwajmy / w grzechow swych uznaniu / w Swiętym obcowaniu. 
15.) Racżże sprawić Panie / w nas upamiętanie / bym pobożnie źyli ' a na ćię patrżyli: Pana łaskawego / wdźień przyśćia twojego / Amen.

Von $1773 \mathrm{ab}$ ist diese Liedform in den schlesischen Kantionalen verbindlich. Ohne Veränderungen wurde der Text, wie ihn KT 1646 aufzeigt, in den schlesischen Ausgaben bis 1890 abgedruckt. Es hat den. Anschein, da $\beta$ das Lied nicht aus dem Deutschen, sondern aus dem Tschechischen ins Polnische übersetzt worden ist, was der tschechische Text veranschaulicht:

KBC 1823 : S. 260 f.

1.) Wesele zpjwegme, a Boha zwy'wegme, genź swého, gednorozeného, dal na wykaupenj, budiź mu chwálenj.

2.) O Krystowu pr'jsstj, ćtweru Pjsmo gistj: Prwnjm w t'elo geho, druhém w duch W'ermého, a tr'entjm pr'i smrti, w ćtwrtém ma sauditi.

3.) Proć pak negprw pr'issel, kdyź z swych nebes wyssel? Raćil sam powédét: aby se dal w obét, mzdu na wykaupenj, za mnohé $k$ spasenj.

4.) Dále téź wyznal sám, r'ka: Pr’jklad dal sem wám, kterak sem gá ćinil, a zákon naplnil; tak téź y wy cińte, wuli Otce plńte.

5.) Druhé prjsstj geho, w mysl srdce lidského, skrz dar wjry bywá; protoź se ozywa: Stogjmi tluka v dver'j kaźdy mi odewr'i;

6.) A wegdut hned mile, obdar'jm té chwjle, pr'edrahau milostj, sebe aućastnostj, skrze Ducha swého, obziwjm Wérného.

7.) Nebi gsem gá winny Kmen, gehoź aućastnost ten, sám toliko mjwá, kdo s mnau spogen bywá, v wnitr'njm źiwotu, skrz Cyrkwe gednotu.

8.) Cále dj: Kdeź dwa dr'j, spolećnosti sstr'j, w mém gménu gá s njmi, Vćastnjky swymi, chcy mjt pr'ebywánj, do swéta skonánj. 
9.) Po tr'ejtj pr'igjti, sljbil kdyź wygjti, z téla wérny Ćlowék, má giź w budaucy wék, $\mathrm{k}$ wyprowozenj ho, dodomu wéćného.

10.) Protoź kázal bdjti, a str'jzliwu byti, by hotowé nassel, kdykoliby k nám ssel. Blaze kdoź se chowá, wedle teho slowa!

11.) A tak se warugme, a neobtéźugme, obźerstwem swych srdcy, opilstwjm a pećj, tohoto źiwota, rada Krystowá ta.

12.) Ćtwrté pr'jsstj bude, kdyź den saudny pr'igde; tot bude hrozny den, kdyź pugdau z hrobu wen, w pr'edessenj wssickni, Bezboźnj a Hr'jssnj.

13.) Neb se Pánem pugdau, y Angelé $k$ saudu, hrozné $\mathrm{k}$ geho hlasu, nebesa se str'asau, a z zázraku mnoho, bude ćasu toho.

14.) Ten den bude auzky, den nahly den, brzky, genź Hr'jssné prikwáćj, co osydlo ptáćj; gjmź zgjmáni budau, w źalár' wéćny pugdau.

15.) Protoź se pr'iprawme, hotowé postawme, k swatému pokánj, a w ctném obcowánj; na modlitbách trzwegme, tak Pána ćekegme.

16.) Rać Pane popr’jti, w twé prawdé wźdy byti, at bychom w nj bd'eli, potom t'e widéli, Pána laskawého w den pr'jchodu twého.

Das tschechische Lied hat 16 Strophen und behandelt auch die vierfache Ankunft Christi gesondert.

$$
\begin{aligned}
& \text { Nr. } 5 \text { "Z pokojem idę w radosci ". } \\
& \text { "Idę w wesołym sumnieniu". } \\
& \text { " Mit Fried und Freud ich fahr dahin". }
\end{aligned}
$$

Als freie Umdichtung des Lobgesanges Simeons, des "Nunc dimittis" ist es wahrscheinlich schon vor 1520 von Luther geschrieben worden ${ }^{15}$ ). Es erschien zuerst in dem sog. Wittenbergschen Chorbüchlein von 1524.

W: S. 142. 
1.) Mit fried vnd freud ich far dahin in Gottes wille,

Getrost ist mir mein hertz vnd sinn, sanfft vnd stille.

Wie Gott mir verheissen hat:

der tod ist mein schlaff worden.

2.) Das macht Christus, wahr Gottes son, der trewe Heiland,

Den du mich, Herr, hast sehen lon,

vnd macht bekand,

Das er sey das leben

vnd heil in nöt vnd sterben. (SG 1718, S. 418 ,not und auch sterben").

3.) Den hastu allen für gestelt

mit grossen gnaden,

$\mathrm{Zu}$ seinem reich die ganze welt

heissen laden

Durch dein tewer heilsam wort

an allem ort erschollen.

4.) Er 'ist das heil vnd selig liecht

für die heiden (SG 1718: wohl für die heiden).

Zur leuchten, (SG 1718: zur erleuchten) die dich kennen nicht,

und $\mathrm{zu}$ weiden.

Er ist deins volcks Israel

der preis, ehr freud vnd wonne.

Die polnische tbersetzung hat zwei Fassungen: 1.) "Z pokojem idę w radośći". 2.) Idę w wesołym sumnieniu". Der Ubersetzer der Variante "Z pokojem idę w radości" war wohl Andreas Kotenius, denn das Lied ist in P 1670 mit A.K. unterzeichnet ${ }^{16}$.

Oloff17 führt das Lied als bereits vorhanden in "Dambrowius Lekarstwo dußne w chorobie" Posen, 1611, an. Nach Kühnast18 befindet es sich aber schon im Thorner Kantional von 1601 unter Nr. 292. 
KG 1646 : S. 462 f. "Pieśni Pogrzebne".

1.) Z pokojem idę $w$ radośći / juź z tąd (K 1673, S. 908 f. ztąd) z Boskiey miłośći / serce me jest uweselone y spokoyne : bo jako Bog prźyrzekł w słowie swym / słodkim ucźynił śmierć moję sn.em.

2.) Ato (K 1673 u. P 1670, S. 212: A to) prźez Syna swojego / Zbawićiela wiernego / ktoregoś mi Panie objawił / znacźnie wystawił / toć (P 1670 : toź) jest moy źywot Zbawienie / w Smutkach y w śmierći Wspomozenie.

3.) Tegoś z laski na świat zesłał / aby Narod (P 1670: aby ten narod ) wezwal / do Krolestwa twego wiecźnego / wiernym sprawionego / prźez Słowo swoje Zbawienie / po wßystkim świećie rozgłoßne.

4.) On jest światłość y Zbawienie / Poganow naprawienie / od niego ći co go nie znają / Oświecenie mają/ on jest Izraela Cźeść prawa / światłość / wiecźna Sława. AK. 19

Die polnische Fassung ist im Vergleich zum deutschen Original ziemlich eigenmächtig. Wenn der tbersetzer sich im allgemeinen eng an die deutsche Vorlage gehalten hat, ihr Sinn vollkommen gewahrt bleibt, so hat er es doch mit großem Geschick verstanden, dem polnischen Liede eine eigene sprachliche Note zu geben. Zu Str. 1: zwischen hertz und sinn macht der Ubersetzer keinen Unterschied. Er setzt für beides serce. Sanfft und stille gibt er durch uweselone y spokoyne wieder. Das uweselone hat die Bedeutung von freudig, fröhlich, frohgestimmt, keineswegs von "sanft". Durch feine Steigerungen wie slodkim snem - während der deutsche Text nur schlaff hat - drükt er die Hingebung und das Fügen des Menschen in den Willen Gottes stärker aus. Zu Str. 2: und macht bekand - znaczne wystawil. Der polnische Ausdruck sagt hier mehr. Durch das macznie wird das bekand besonders betont, etwa "eindrücklich". Heil hier zbawienie, was eine weitere Steigerung ist. Das 
Wort Wspomoźenie, Beistand ist gegen den deutschen Text zugefügt. Trotz oft genauester Wortübersetzung erscheint die polnische Fassung als im christlichen Sinne "idealisierter". Die Ubersetzung " $Z$ pokojem idę w radośći" von $A n-$ dreas Kotenius wurde nur in die schlesischen Kantionale von 1670 und 1673 aufgenommen. Alle späteren polnischen Kantionale haben durchweg die Variante "Idę w wesołym sumnieniu" bevorzugt. Nur K 1673 hat beide Fassungen berücksichtigt.

KT 1646: Mit deutscher Uberschrift auf S. 318 unter den "Pieśni Pogrzebne".

Str. 1.) Idę w wesołym sumnieniu / do Pana mego, upewniony o zbawieniu / słowem jego: Juź dokonaw $\beta y$ tu (K 1804, Nr 29: to boiu ) boju / śiędę sobie w pokoju.

Str. 2.) To mi Syn Boga źywego / Pan Jezus sprawil : W ktorym zmiłośierdźia (K 1663, S. 907 : z miłosierdzia swego u. K 1790, S. 907: o ktorym z miłosierdzia swego) swego ! Bog mi stawił : Nad Smierćią (K 1790: "nad śmiercia" als Druckfehler) triumf bezpieczny / y Skarb źywota wiecźny.

Str. 3.) Jak do Chorągwie20 (K 1861 : Jak pod chorąiew) do niego / Bog miłośierny / zbiera wybrania swojego / Narod wierny : Przez Mandat21 Słowa wiecźnego) na ćały krąg bzrmiącego.

Str. 4.) Jezu Narodow Pogańskich / wiecźną światłośći / Sławo włośći22 (K 1804, Nr. 29 : Chrześciańskich ) ma radośći : Juź kiedy chce $\beta$ bierz do śiebie / daj bydź co rychliey w Niebie. Amen.

Nr. 6 "Jezu ktoryś śmierći sam skoßtowal." "Jesu, der du selbsten wol".

Der Verfasser dieses Gesanges ist Michael Babzien4.

SG 1718: S. $245 \mathrm{f}$. "Vom Leiden und Sterben Jesu Christi". Mel. Einen guten kampff hab ich. 
1.) Jesu der du selbsten wohl Hast den Tod geschmecket , Hilff mir / wenn ich sterben soll / Wenn der tod mich schrecket / Wenn mich mein gewissen nagt / (FischerTümpel, I, S. 403: plagt) Und die sünden plagen / (Fischer-Tümpel: nagen) Wenn der satan mich verklagt / La $\beta$ mich nicht verzagen.

2.) Jesu / zeige mir die seit / Und die rothen wunden / In den letzten scharffen streit Meiner todes stunden / La $\beta$ mir deinen bittern tod / Blut und angstschwei $\beta$ nützen / Wenn ich in der letzten noth Todesschwei $\beta$ (FischerTümpel: vor dem Tode) soll schwitzen.

3.) Von dem speer der letzte stich Naht (Fischer-Tümpel: Geht) dir zu dem hertzen: Ach Herr Jesu / denck an mich / Fühlt mein hertz auch schmertzen. Blut und Wasser vor dir fleusst / Laßt mich dieses laben / Wenn mein schwacher matter Geist Todesdurst wird haben.

4.) Jesu meines lebens licht / Dich nicht von mir wende / Ach Herr Jesu / la $\beta$ mich nicht An dem letzten ende / Jesu reisse mich / mein schutz / Aus des todes rachen / (Fischer-Tümpel: Au $\beta$ der Höllen-Rachen) Ach ein tröpfflein deines bluts / Kan mich selig machen.

Georg Heinrich Assig, polnischer und deutscher Prediger zu Postelwitz bei Bernstadt in Schlesien, ist als polnischer Ubersetzer dieses Gesanges anzusehen ${ }^{25}$. Er gab dem Liede in der Ubersetzung die Worte: “Jezu ktoryśśsmierći sam sko $\beta$ tował, ${ }^{26}$ als Anfangstext.

K 1773 : S. 144 "Pieśni o męce i śmierci Jezusowey".

Der deutsche Anfangstext des Liedes befindet sich über dem polnischen.

1.) Jezu ktoryś śmierći sam skoßtował gorskośći, wspomoż gdy umierać mam mnie w śmierci srogośći, gdy strapione sumnienie ćięźar grzechow czuie, na diabła oskarzenie niech nie desperuie.

2.) Jezu pokąz mi bok twoy, i czerwone rany,27 gdym w ostatny tęgi boy godźin śmierći dany, day ze me 
poźytki mam z gorski śmierći twoiey, gdy iuź zimny pot miewam w straßney chwile moiey.

3.) Od włoczni ostatny (K 1776, S. 168: "ostatni") $\beta$ tych ${ }^{28}$ w serce idźie tobie, ach boleśći serdecznych Jezu mych bacz sobie! Twoiey krwie a wody zdroy niech mnie mocno (hoynie in $\mathrm{K}$ 1776) chłodźi, kiedy duch zemdlony, moy, w pragnienie przychodźi.

4.) Jezu źyćia światłośći moia nie oddalay śię odemnie w słabośći, ani mnie opußczay! Jezu tyś obrońca

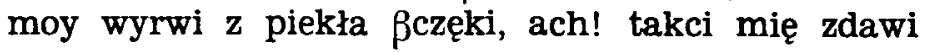
znoy twoiey męki.

K 1776: Weitgehende Textänderungen hat das Lied im Bockshammerschen Gesangbuch. Die 1. Strophe lautet etwa von der Hälfte ab (S. 168) : - gdy strapione sumnienie na grzech utyskuie, porady źadney w sobie nie pociechy czuie. Auch die 2. Strophe hat ein anderes Aussehen : Jezu pokąz mi bok twoy, i czerwone rany, gdy w ostatni śmierci boy będę iuz podany. Kiedy strach i teskności, pot mi wyciskaią, niech mnie krwawe znoie twe Jezu! oczerstwiaia. Die 4. Strophe weist wieder eine vollkommen andere Fassung auf, die dann alle anderen Herausgeber schlesischer Kantionale übernommen haben: Jezu świeć mi, kiedy się oczy

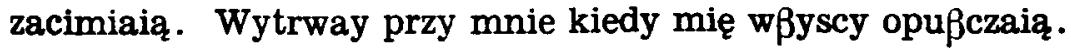
Jezu Doycięzco29 wyrwiy mnie z śmierci paßczęki : by daremne nie były Twoie za mnie męki.

Auch K 1804 übernahm die Aenderungen des Liedes im Bockshammerschen Kantional. In der zweiten Strophe hat K 1804, S. 112, Nr. 28 für teskności richtig tęskności.

Nr. 7. "Panie Jezu tyś Człowiek y Bog", bzw.

"Jezu Christe wiecznie źywy Boze".

"Herr Jesu Christ war Mensch und Gott".

Das Lied stammt von D. Paul Eber ${ }^{30}$ ). Im Hamburger Gesangbuch von 1565 ist es mit: D.P. Eberus Filiolis suis faciebat ${ }^{31}$ ) unterzeichnet. 
W: S. 380. "Betlied zu Christo vmb eyn seligen abscheyd. In der Melodej, Vatter vnser im Himmelreich etc.".

1.) Herr Jesu Christ, war Mensch und Gott, der du littst marter, angst und spott, Für mich am Creuz auch endtlich starbst vnnd mir deins Vatters huld erwarbst:

Ich bitt durchs bitter leiden dein, du wölst mir Sünder gnedig sein!

2.) Wann ich nun komm in sterbens noth vnnd ringen werde mit dem Tod, Wann mir vergeht all mein Gesicht vnd meine Ohren hören nicht, Wann meine Zunge nichts mehr spricht vnd mir vor angst mein Hertz zerbricht!

3.) Wann mein verstand sich nichts mehr bsinnt vnd mir all Menschlich hilff zerinnt: So komm, Herr Christe, mir behend zu hilff an meinem letzten end Vnd führ mich aup dem jammerthal, verkürtz mir auch des Todes qual!

4.) Die bösen Geyster von mir treib, mit deinem Geyst stäts bei mir bleib, $B i \beta$ sich die Seel vom Leib abwend, So nimm, sie, Herr, in deine Händ! Der Lieb hab in der Erd sein ruh, bi $\beta$ sich der Jüngst tag naht herzu.

5.) Eyn fröhlich Vrständ mir verleih, am jüngsten gricht mein Fürsprach sey Vnd meiner Sünd nicht mehr gedenck, au $\beta$ gnaden mir das Leben schenck, Wie du hast zugesaget mir in deinem wort, das traw ich dir: 
6.) Fürwar, Fürwar, euch sage ich:

wer mein wort hällt vnd glaubt an mich,

Der wird nicht kommen ins Gericht,

vnd den Tod ewig schmecken nicht,

Vnd ob er schon hie zeitlich stirbt,

mit nichten er drumb gar verdirbt!

7.) Sonder ich will mit starker Hand

jhn reissen au $\beta$ des Todes band

Vnd jhn mit nemmen in mein Reich,

da soll er dann mit mir zugleich

In freuden leben ewiglich!

darzu hilff vns ja gnediglich!

8.) Ach Herr, vergib all unser schuld!

hilff, das wir warten mit gedult, bi $\beta$ vnser stündlein kompt herbei!

auch vnser Glaub stäts wacker sei,

Deim Wort zu trawen festiglich,

bi $\beta$ wir entschlafen seliglich!

In vielen Gesangbüchern kommen diese 8 sechszeiligen Strophen als 12 vierzeilige vor, so zuerst in den Kirchengesängen der böhmischen Brüder von $1566{ }^{32}$ ). Auch das vollständige Gesangbuch „Kirchen- und Hausmusik” von $1611 \mathrm{zu}$ Görlitz, in fünfter Auflage zu Breslau gedruckt, bringt diesen Gesang in 12 Vierzeilern; desgleichen hat das schlesische Kirchengesangbuch - von Breslau und Liegnitz im Jahre 1718 die aus 12 Strophen bestehende Fassung des Liedes auf S. 392 unter der Rubrik „Vom Tode und dem ewigen Leben".

Die polnische Fassung "Panie Jezu tys Człowiek y Bog", die dem deutschen Text entspricht, ist (nach Oloff, $\mathbf{S}$. 62) eine Ubersetzung von Caspar Gesner ${ }^{33}$. Sie besteht gleichfalls aus 12 vierzeiligen Strophen. Eine andere Uberarbeitung dieser Fassung ist der Gesang "Jezu Christe wiecźnie żywy Boźe".

KG 1646 : S. 466 ค. "Pieśni O Smiertelnośći". tuberschrieben mit deutschen Anfangstext. 
1.) Panie Jezu tyśs Człowiek y Bog / ćierpiałes męki, źimno, głod / na krzyźuś za mię źywot dał / z Oycemeś mię swym pojednał.

2.) Proße ćię dla męki twojey / trźymay mię w opiece (w opie ce als Druckfehler getrennt in P. 1670, S. 213 f.) swojey / gdy juź na ostatnią przyjdę / a z śmiercią Trwogi nie uydę.

3.) Gdy Śię zaćmią moje Ocźy / nie usłyßą nic me Vßy / Język moy mówić nie będźie / a Serce mi śię rozsiądźie (K 1741, S. 328 : rozsiędzie).

4.) Gdy śię w/3ystek zapamiętam / ludzkiey Pomocy nie uznam / w ten Cźas prźyjdź ô Jezu miły / pomoź mi w ostatniey chwili.

5.) Wywiedź mię sam z złych Przepaśći / skroć mi śmiertelne Boleśći / Ducha złego teź precź odpądź Duchem swym zawźdy przy mnie bądź.

6.) Dußa ma skoro wynijdźie / w twych Rekkach Panie niech będzie / niechay ciało w źiemi leźy / aź się sądny Dźień przyblizy.

7.) Day mi wesoło zmartwychwstać / w Dzień sądny o mię (K 1673, S. 891 : o mnie) mowić racz / Grzechow mojich zapamiętać / $\mathrm{z}$ łaski swey Zywot wieczny dać.

8.) Tak jakoś mi przerzec raczył / w Słowie swym mocnie upewnił / Zaprawdę wam mowię / Kto mnie słucha a wierzy w mię.

9.) Tenći juz na Sąd nie przyjdźie / wieczney śmierći pewnie uydźie / choćby tez tu umarł cześnie / wzdy jednak nie zginie wiecznie.

10.) Bowiem ja Pan wßechmogący (K 1741 wßechmogąci) wyrwę (P 1670 wyrwęgo) go z okrutney śmierći / y przyjme (przyymę in K 1741) w Krolestwo swoje / gdźie więc ma być zemną rownie: 
11.) W weselu w zywocie wiecznym ; Pomoz nam Panie tam wßystkim / Panie odpuść naße Winy / day byśmy ćierpliwi byli.

12.) Czekając godźiny cześney / doday ty nam wiary mocney przy słowie twojim stale trwać ! poki nas tu raczy $\beta$ chować.

KT 1646 : S. 317 f. "Pieśni Pogrzebne". Mit deutscher Uberschrift: "Herr Jesu Christe wahr Mensch vnd Gott".

1.) Jezu Christe (Kryste in $K$ 1673) wiecźnie źywy / Boze Człowiecze pradziwy: Tyś by twoj Oćiec przebeaczył / mych win za mię nieść raczył.

2.) Proßę dla śmierći twojey / bądź miłośćiw Dußy mojey: Kiedy zła chwila przypadnie / gdy mię gwałt śmierći opadnie (K 1761 popadnie, K 1790 S. 454: napadnie).

3.) Gdy zajdźie (K 1861: zginie) moj wzrok / słuch / mowa / a na pował lęgnie (K 1741: legnie) głowa : Gdy ni mych wrodzonych mocy / ni ludzkich stanie pomocy (K 1861: "gdy od mych wrodzonych mocy, od ludzi niemam pomocy") .

4.) Gdy serce moje zdrętwieje / gdy w $\beta$ ystkie zpełzną nadźieje: Przybądz Jezu / Jezu rata! podaj Ręki / prowadź z Swiata.

5.) Ukroć mąk / ulźej (K 1741 ulźyy) cięßkości / śmierći ujmi surowości: Opądź przecź Czarta sprosnego / przydaj Anjoła świętego.

6.) Gdy śię Duch z ciałem rozstanie / racz go wźiąc w ręce swe Panie: Ciału zaś po czesnym boju / daj wytchnąc wźiemnym pokoju.

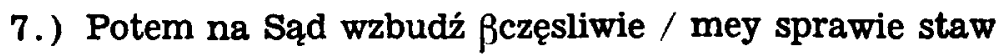
się źyczliwie: A przepomniaw $\beta$ y w $\beta e c h$ złośći / wzdaj (K 1861: daj) mi z laski wieczme włośći.

8.) Bo to mam za prawdę ista / coś rzekł zprzysięga dwojistą: Amen ${ }^{34}$ Amen kto wmię wierzy / takiego grob nieudźierzy. 
9.) Lecz przez ćiasne śmierći wrota / juz przestąpił do źywota: A ja dnia ostatecźnego / wzbudzę z prochu ćiało jego.

10.) Gdźiem ja jest chce aby byli / ći co mi wiernie shuźyli, Aźeby z mojey sławnośći / wieczne cźerpali radośći.

11.) O Panie zatar $\beta y$ długi / bądź łaskaw na nas swe sługi (twe sługi in $\mathrm{K} 1861$ ): Trzymaj słowo a wiernego / dodaj nam serca do niego.

12.) Trudney ostateczney chwile przypilnuj (K $1741 \mathrm{u}$. K 1761 przypilnuy) nas w Boskiey śile: Racź do zgonu o nas radźić / racź ßcźeśnie w niebo przesadźić. Amen.

In den älteren schlesischen Kantionalen kommen immer beide Fassungen des Liedes vor. In P 1670 wird "Panie Jezu tyś człowiek y Bog" als Text nach der alten Edition bezeichnet. In K 1741 und $K 1761$ ist diese Liedfassung als "Inßa Edycya" gekennzeichnet. Das Kantional von 1773 (K 1773) enthält bereits nur die Variante "Jezu Chryste wieczne żywy Boźe". Für die späteren Gesangbücher wird dann dieser Text verbindlich und hat sich auch allgemein durchgesetzt. Während in den schlesischen polnischen Kantionalen die Liedvariante "Panie Jezu tys Człowiek y Bog" bis in die neuere Zeit hinein sich nicht durchgesetzt hat und infolge ihrer Nichtaufnahme in die Gesangbüucher bald in Vergessenheit geraten ist, konnte sie sich in den Königsberger polnischen Kantionalen bis in die neueste Zeit hinein behaupten. In KP 1915 steht das Lied nach der alten Fassung auf S. 617 unter der Rubrik "O śmierci i zmartwychwstaniu", mit der Aenderung v. czlek für czlowiek. Diese Aenderung war durch das Metrum bedingt.

In allen älteren schlesischen Kantionalen treten vielfach die Lieder in verschiedener Textkomposition auf, die aus Thorner und Danziger Gesangbüchern zusammengestellt sind. Die Angabe von zwei verschiedenen Lesearten 
in den Liedern ist für die Entwicklung des Kirchengesanges als hemmend zu bewerten. Da durch den Druck zweier voneinander abweichender Lieder die Singemöglichkeit in ihrer Vielfältigkeit nur noch erweitert wurde, mußte der Gesang im Volke sich noch verworrener gestalten. Die Gläubigen, die an einen bestimmten Wortlaut gewöhnt waren, bekamen nun einen geänderten vorgesetzt und mußten infolgedessen an der Richtigkeit ihrer Singtexte zweifeln. Ein Ineinandersingen von zwei Fassungen war häufig im kirchlichen Gemeindegesang die Ursache zur Entstehung einer dritten Liedvariante. Anstatt dem Gesang in Varietäten durch den Druck eines verbindlichen Liedtextes Einhalt zu gebieten, verschlimmerten die schlesischen Gesangbücher mit dem Druck von zwei verschiedenen Texten diesen tubelstand in außerordentlichem Maße. Das schlesische Kantional von 1673, das die späteren schlesischen Gesangbücher in Text und Liedanordnung nachahmten, hat durch den Druck in der Zusammenstellung nach Thorner und Danziger Liedersammlungen, in der Aneinanderreihung von Liedvarianten, dieses Ubel auf schlesischen Boden übertragen und dadurch dem Zersingen eines Liedes Vorschub geleistet. Erst mit Beginn der von Christian Bockshammer herausgegebenen Gesangbücher, also vom Jahre $1776 \mathrm{ab}$, wird dieser Mi $\beta$ stand durch den Druck eines verpflichtenden Liedtextes beseitigt, die Variante verdrängt und die Möglichkeit des allgemeinen Bekanntwerdens eines nun verbindlichen Textes gegeben. Neben den bereits angeführten Liedern besitzt K 1673 fast unter jedem Liederabschnitt 2 Varianten eines Liedes.

Auf S. 14 in K 1673 hat das Lied "Prźydź o Zbawienie Pogańskie" (unter den "Pieśni Adwentowe") neben der Fassung, wie sie KT 1646, S. 17 aufzeigt, mit gleichem Anfangstext noch eine andere, die mit der von $\mathrm{KD}$ 1646, S.17 übereinstimmt. Beide Fassungen weichen voneinander in der fünften, sechsten und siebenten Strophe $a b$ :

KD 1646: S. 18, 5 Str. "Tuć k nam od Oyca przybiezał / do Oyca się zaś wezbrał / pottumił piekielne Mocy / jest 
Boga na Prawicy". Str. 6 : "Ty ktoryś rowien Oycu sam / pomoz nam w ćiele jako Pan / Aby twa laska Moc wieczna / nam wßem była pomocna". Str. 7: "Tweć jastłka nam świecą jaśnie / Zorza jasna niezagaśnie / Ciemność tez nic nie uczyni / Nam gdyz w cię mocnie wierzymy. K 1673, S. 16 hat Jastka. $P 1670$, S. 12 hat genau nach KD 1646 iastlka. In P 1670 ist jedoch der Anfangtext mit "Przydź zbawienie Pogańskie" unterschiedlich. Das Lied ist hier mit deutschem und lateinischem Wortlaut "Nun kom der Heyden. Heyland" und "Veni Redemptor gentium" überschrieben.

KT 1646: S. 18, Str. 5 : "Przyßedł do Ojca wiecznego / y zaś odßedł do niego / pothumił piekielne mocy / jest u Boga na prawicy". Str. 6 : "Ktoryś rowny Ojcu swemu / pomoź ludowi twemu / aby twa łaska / moc wieczna / w $\beta y$ stkim była pozyteczna. Str. 7: "Twe jasłka niech świeca jaśnie / zorza jasna niegaśnie / ciemność temu niezaßkkodźi / Co w swiatłości wiary chodźi. K 1776 S. 78 : Jasłka erläutert Bockshammer mit "t. i. złob świeci iasnie świadcząc o wielkiey miłości Jezusowey, ktory śię tak głęboko dla nas uniźył ". K 1776 weist in dieser Strophe noch mehrere Aenderungen auf. Sie hat hier folgendes Aussehen: Twe iasłka niech swieca iaśnie, niech twa chwała nie zgaśnie, ciemność temu nie zaßkodzi, co w swiatłości wiary chodzi. Dem zgaśnie fügt Bockshammer durch eine Anmerkung die Erweiterung w nas hinzu. Für ciemność gibt Bockshammer in. K 1776 die theologische Erklärung : to iest grzech i kara za grzech. $\mathrm{K} 1804$, S. XIV. Nr. 6 hat $\mathrm{z}$ T. die erläuternden Fupnoten von $\mathrm{K} 1776$ zu Textänderungen verwandt. Bei Chuć beginnt die 7. Strophe mit "Twoy złob niech nam świeci". Der weitere Text richtet sich in K 1804 nach K 1776. K 1804 weist auch für jasłka das neuere źlob auf. Fiedler benutzt in $\mathrm{K} 1861$ auf $\mathrm{S} .78$ den von Bockshammer beibehaltenen Ausdruck jasłka.

Bis 1773 bringen die schlesischen Gesangbücher beide Fassungen nach dem Thorner und Danziger Kantional. Von $1773 \mathrm{ab}$ tritt in der Reihe der gedruckten Gesänge nur eine Fassung auf, und zwar die des Thorner Kantionals von 1646. 
In den meisten Fällen ist es möglich festzustellen, da $\beta$ sich die Fassung eines Liedes, wie sie in den Thorner Gesangbüchern üblich ist, in Schlesien von 1773 oder von 1776 ab allgemein durchsetzt. Das Bockshammersche Gesangbuch (K 1776) versieht den Text eines Liedes mit verschiedenen Erläuterungen, die dann Robert Fiedler in der Verbesserung des Bockshammerschen Gesangbuches entweder streicht oder aber oft im Text verwendet. Nach Oloff ${ }^{35}$ besitzt das Passionslied "Rozmyślajmy dziś wierni Krześcianie" in K 1673 (S. 131) eine weitgehende Anänderung, die dahin abzielt, in der 12. Strophe dieses Gesanges die Höllenfahrt Christi auszulassen. Es ist nicht der 11., wie Oloff angibt, sondern der 12. Vers im Liede. KT 1646 (S. 71) zeigt die Höllenfahrt Christi in der 12. Strophe mit den Worten an: "Zstąpił do piekła / mocą swego Bostwa: Tamże oświadczył / znak swego zwyćięstwa: Ciała umarłe z grobow powstawały widzieć śię dały". Der 12. Vers (in $K 1673$ ) hat dagegen eine andere Gestalt: "W tym śię kośćielna prźerwała Zasłona / więc y Skał twardych Moc była skrußona: Ciała umarłe z Grobów powstawały / widźieć śię dały". Diese Fassung haben dann alle späteren schlesischen Gesangbücher übernommen. Das erste schlesische Kantional (P 1670) bringt dagegen im 12. Vers den wörtlichen Thorner Text. Es ist nicht anzunehmen, da $\beta$ die Abänderung der 12 . Strophe in $\mathrm{K}$ 1673 und in allen späteren, sich nach $K 1673$ richtenden schlesischen Gesangbüchern ohne eine andere Vorlage selbständig erfolgt ist, sondern sie beruht sicher auf irgendeiner anderen Thorner oder Danziger Vorlage, die auch schon den Text, wie ihn K 1673 verzeichnet, trägt.

Eine selbständige Variante, die Oloff in seinem Werk auf. S. 298 erwähnt, bietet das Lied "Pan na $\beta$ wtory Adam z Nieba" ("Pieśni Na Wielki Czwartek" in K 1673, S. 168). Das alte Thornische Kantional hat im 21. Vers dieses Liedes die Worte: "dayźe usty źywey wiary". K 1673 dagegen hat Dayźe Ręką źywey Wiary, wodurch der gar zu deutliche Kalvinismus in der Thorner Fassung gehoben worden ist um hier Ollofs Ausdruck zu gebrauchen. Auch diese Text- 


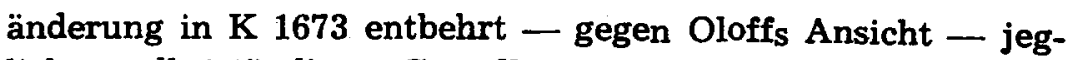
licher selbstständigen Grundlage; denn schon ältere Thorner und Danziger Gesangbücher weisen genau dieselbe Aenderung wie in K 1673 auf. Mit gleichem Text, wie inn $\mathrm{K} 1673$ bietet, ist das Lied bereits in KD 1646 (S. 117) und KT 1646 (S. 86) zu finden.

Zwei Fassungen weist K 1673 (S. 44 f.) des Liedes "Nastał nam dzień poządany" auf. Die erste Fassung richtet sich im Text genau nach dem Wortlaut, wie ihn KT 1646 (S. 41, "Pieśni O Narodzeniu Pańskim") aufzeichnet. Die zweite Fassung, die in K 1673 als "Albo wedhug starey Edycyey "mit dem Anfangstext "Nastałći nam dzień wesoły" bezichnet wird, gleicht vollkommen dem Text von KD 1646 (S. 40). In K 1741 ist das Lied im "Przydatek", mit der deutschen tuberschrift "Uns ist gebohren ein Kindelein", in jedoch von der Thorner und Danziger gänzlich abweichender Fassung zu finden. Während es in K 1673 nach der Thorner und Danziger Fassung aus 14 Strophen besteht, hat es in $\mathrm{K} 1741$ nur 5 Strophen. Der Verfasser dieses Liedes ist Christian Rohrmann. Die folgenden Strophen haben dann in alle späteren Gesangbücher Aufnahme gefunden, so da $\beta$ die in den älteren schlesischen Gesangbüchern abgedruckten Fassungen, nach Thorner und Danziger Vorlagen, in Vergessenheit geraten waren :

1.) Nastałći nam Dźien wesoły w ktorym z Panny czystey narodźił śię Syn Boży : / narodźił śię Syn Boży.

2.) Ktoremu Kyśieżyc i Słońce i gwiazdy niebieskie, służą na czasy swe :/: służą na czasy swe.

3.) Chwalmyź go z takiey Miłośći, w Chrześćiańskiey Jednośći, z serdeczney wdźięcznośći :/: z serdeczney.

4.) Dźiękuiąc mu po wße czasy, iż nas raczył wyzwolić, od Dyabelskiey mocy :/: od Dyabelskiey mocy.

5.) Bądź Chwała Oycu wiecznemu, Synowi iedynemu, i Duchowi swiętemu :/: i Duchowi S.

Das älteste schlesische Gesangbuch, P 1670, richtet sich im Text dieses Liedes nach der Fassung von KD 1646. Da $\beta$ 
eine auf schlesischem Boden entstandene Variante eines Liedes sich allgemein durchgesetzt und sogar die alten Thorner und Danziger Kompositionen verdrängt hat, gehört zu den äußerst seltenen Erscheinungen in der Geschichte des schlesischen Kantionaldruckes und ist nur mit der Persönlichkeit Christian Rohrmanns, als hervorragenden Ubersetzers und Liedschöpfers, in Zusammenhang zu bringen.

In den ältesten schlesischen Kantionalen tritt auch das Lied "Mądrość Ojca Wßechmocnego" mit einigen Textvarianten in der 2., 5., und 14 . Strophe auf, die durch die Verschiedenartigkeit der Texte des Danziger und Thorner Kantionals von 1646 begründet sind. P 1670 (S. 40) besitzt den Text von KD 1646. (KD $1646 \mathrm{~S} .93$ "Pieśni O Umęcżeniu Panskim") . 2.) W wielkiey pokorze / w ćichośći / nie litując swey trudnośći / dla narodu człowieczego / widząc wielki vpad jego. 5.) Stał na Krzyzu zawießony / w $\beta$ ystek swiętą Krwią skropiony wołając $\mathrm{z}$ wielkiego pragnienia / nędznemu człeku zbawienia. 14.) Bo wielicesmy zgrzeßyli / Majestat twoy obraźili / wßakze z swey Boskiey miłośći / racz odpusćić naße złośći / a przyjmi nas ku radośći.

Die Thorner Fassung (KT 1646, S. 70), die in K 1673 und in allen späteren schleischen Kantionalen vertreten ist, unterscheidet sich dagegen in den betreffenden Strophen von KD 1646 :

KT 1646 : S. 70, 2.) W wielkiey pokorzy / w ćichosći nie zbraniając śię trudnośći dla narodu człowieczego / widząc wielki upad jego. 5.) Stał na krzyżu zawießony / wßystek świętą krwią skropiony / wołał pragnę ochłodzenia / życżiąc ludźiom y zbawienia. 14.) Bom wielce wßyscy zgrzeßyli / Majestat twoj obraźili / wßakźe z swey boskiey miłośći / racż odpuśćić naße złośći / a przyjąć nas do radośći. Amen.

Durch P 1670 wurde das Lied, wie es KD 1646 enthält, in Schlesien bekannt. Der Druck des Liedes in K 1673 hält sich an KT 1646 und bleibt dann für alle schlesischen Gesangbücher verbindlich. 
Durch den Druck zweier Liedkompositionen, wie es mit $\mathrm{K} 1673$ angefangen bis zu dem von Jerzy Szlak herausgegebenen Gesangbuche ( $K$ 1773) oft der Fall war, wurden die unterschiedlichen Texte nebeneinander gereiht und wirkten sich für den Kirchengesang bestimmt nicht zum Vorteil aus; sie vergrößerten die Möglichkeit des Zersingens eines bisdahin im Text authentisch feststehenden und vielleicht althergebrachten Liedes. $\mathrm{Da} \beta$ die späteren Gesangbücher, in der Hauptsache mit $K 1776$ beginnend, sich zum Druck nur eines Textes entschließen und die Liedvariante aus der Reihe der Gesänge entfernen, war m. E. für den Gesang und die Verbreitung des Liedes nur von Nutzen.

Die angeführten Beispiele werden genügen, um die große Abhängigkeit des schlesischen Kantionaldruckes von den älteren polnischen Danziger und Thorner Vorläufern zu beweisen. Die Lieder wurden in die schlesischen Gesangbücher in der gleichen Art aufgenommen, wie sie in Thorner und Danziger Liederbüchern anzutreffen sind. Sie wurden sogar mit denselben dort vorkommenden Druckfehlern in Schlesien abgedruckt.

Nachdem alle älteren Kantionale in Schlesien, etwa bis zum Jahre 1773, oft zwei Fassungen eines Liedes, wie sie in Thorn und Danzig zu singen üblich waren, aufzeigen, bildet sich dann, etwa vom Jahre 1776 ab, eine einzige Liedfassung heraus, die Variante wird verdrängt, und ein einziger Text wird bindend.

Auch das Vorkommen der oft doppelten Liedkompositionen in den älteren schlesischen Kantionalen ist ein Zeichen für die Unselbständigkeit, die man im Kantionaldruck in Schlesien walten lie $\beta$. Da in Thorn, Danzig, aber auch in anderen älteren polnischen Vorbildern die verschiedensten Kompositionen eines Liedes bekannt waren, so konnte man es auch in Schlesien, vielleicht aus einem Gefühl von Unsicherheit heraus, nicht unterlassen, dem Volke verschiedenartige Fassungen zu vermitteln. Die Verfasser frühester schlesischer Kantionale brachten es nicht fertig, sich zu 
einer Liedform zu entschließen. Ob diese Art des Verfahrens auf die Gewissenhaftigkeit der Verfasser, die Lieder möglichst getreu zu übermitteln, zurückzuführen ist, bleibt anheimgestellt. Jedenfalls charakterisiert sie die Unselbständigkeit und damit die völlige Abhängigkeit von außen im Druck der ersten polnischen Kantionale in Schlesien.

Die sprachliche Form der Lieder, wie sie im damaligen Großpolen, vielleicht auch in Thorn, verständlich war, wurde durch die getreue Ubertragung nun auf schlesischem Boden verbreitet. Viele Ausdrücke und Wendungen in den Texten mußten den polnisch sprechenden schlesischen Protestanten unverständlich gewesen sein. Worte, die man in Polen, nicht aber in Schlesien verstand, wurden im Druck, ohne sie der Mundart anzupassen, verbreitet. Der größjte Teil der Lieder, deren Ursprung Polen war, ist in Schlesien vorher kaum bekannt gewesen. Man hat den Eindruck, daf damit auf schlesisches Gebiet etwas Fremdes übertragen wurde. Ein künstlich entstandener Zustand wurde damit in Schlesien weitergezüchtet. Die Angelegenheit rückt in ein anderes Blickfeld, wenn man bedenkt, da $\beta$ sich Großpolen früher gleichfalls der zu Thorn und Danzig gedruckten polnischen Kantionale bediente. In Schlesien wirkten während des 17. und 18. Jahrhunderts manche Geistliche aus Großpolen mit polnischer Muttersprache. Durch sie wurden viele Gesänge, die bisher in Schlesien unbekannt waren, in die Wahlheimat eingeführt. Man kann annehmen, da $\beta$ diese Seelsorger besonderen Ehrgeiz an den Tag legten, ihrer Kirchengemeinde solche Lieder in ihrer Muttersprache beizubringen, die ihnen ebenfalls bekannt waren. So wird für die Verbreitung dieser Lieder in Schlesien nicht immer ein religiöses Bedürfnis im Volke die Ursache gewesen sein.

Alle schlesischen Gesangbücher sind mehr oder weniger ein "Abklatsch" der zu Thorn und Danzig gedruckten Veröffentlichungen. Das erste schlesische Gesangbuch, $P$ 1670, richtet sich ganz in der Komposition der Lieder nach KD 1646, das eine spätere Auflage des Thorner Kantionals vom Jahre 1601 ist. Da K 1673 Lieder mit Doppelkomposi- 
tionen auf schlesischen Boden überträgt, haben alle späteren Kantionale die Möglichkeit, die Gesänge nun aus einer Hauptquelle zu beziehen. Die von Rohrmann und Schlag später herausgegebenen Gesangbücher stellen nur eine Verbesserung und wesentliche Verringerung der Liederanzahl des Kantionals von 1673 dar. Erst Christian Bockshammer bringt mit dem Jahr 1776 neue Gesichtspunkte in die Kantionale herein. Die zahlreichen Fußnoten, die er den Texten als Erläuterung beigibt, legen Zeugnis davon ab, wie wenig an der Erneuerung der Sprache in den schlesischen Gesangbüchern gearbeitet worden ist. Wenn sich Bockshammer entschlo $\beta$, den Texten Erklärungen beizugeben, so ist anzunehmen, da $\beta$ die Sprache der Kantionale zu seiner Zeit - und vielleicht schon ein Jahrhundert vorher - vom Volke nicht mehr recht verstanden worden ist. Seine Erklärungen beschränken sich nicht nur auf theologische Begriffe, sondern berücksichtigen vielfach auch sprachliche Formen und Wendungen. Robert Fiedler, der dann das Bockshammersche Gesangbuch in verbesserter Form herausgab, lie $\beta$ die Methode der erläuternden Fußnoten fallen. Dafür durchsetzte er die Texte, soweit es möglich war, mit Sprachneuerungen. Diese schlesische Kantionalgruppe hebt sich deutlich als Fortsetzung der von Thorner und Danziger Kantionalen vorgezeichneten Linie ab. Die schlesische Kantionallinie mit P 1670 - K 1673 - Rohrmann - Schlag - Bockshammer - Fiedler kann man somit nicht als eigene Gruppe ${ }^{36}$, sondern nur als Ubertragung und Fortsetzung von Danziger und besonders Thorner Schöpfungen dieser Art auf schlesischem Boden ansehen. Die ursprünglichen und schöpferischen Momente, die in schlesischen Kantionalen natürlich auch auftreten, liegen besonders in der Bereicherung der polnischen Hymnologie durch . hervorragende Persönlichkeiten wie Herbinius, Herden und Rohrmann als Liederdichter polnischer und Úbersetzer deutscher Gesänge. Mit diesen Männern hat Schlesien einen besonderen Anteil an der Blüte des polnischen evangelischen Kirchenliedes. Ihre Schöpfungen wurden auch in viele andere polnische $\mathrm{Ge}$ - 
sangbücher außerhalb Schlesiens aufgenommen. Als Neuerungen können die schlesischen Gesangbücher gegenüber Thornern und Danzigern für sich buchen:

1.) In keinem schlesischen Kantional, mit Ausnahme von P 1670, wo den Psalmen Davids Noten beigegeben sind, sind die Texte mit Noten versehen. Das Weglassen der Noten in Kirchengesangbüchern war aber gegen Ende des 17. und 18. Jahrhundert eine allgemeine Erscheinung, die durch die Verteuerung des Notenbeidrucks bedingt war.

2.) Die Entfernung der Psalmen Davids. In den ersten schlesischen Gesangbüchern, besonders in P 1670 und K 1673 nehmen die Psalmen Davids noch einen breiten Raum ein. Allmählich wird ihre Zahl geringer, bis sie schließlich verschwinden. Dies kann vielleicht nur Schlesien für sich in Anspruch nehmen; denn in neuerer Zeit, in KP 1915, sind die Psalmen Davids den Liedern noch beigedruckt. An Stelle der Psalmen Davids treten in den schlesischen Gesangbüchern die Liederbeigaben oder Beidrucke, "Przydatek Piesni" genannt.

3.) Das Druckbild zeigt oft vollausgedruckte, mit großen Buchstaben versehene Wörter, meist bei heiligen Namen und religiösen Begriffen, auf die der Leser besonders seine Andacht und Aufmerksamkeit richten soll. So ein Druckverfahren findet man gerade häufig nur in deutschen Kirchengesangbüchern. Da die Druckereien und Drucker der polnischen Kantionale in Schlesien als Deutsche mit dem Druckverfahren deutscher Gesangbücher voll vertraut waren, wurde diese Technik von ihnen auch beim Druck polnischer Gesangbücher angewandt.

Jeder Herausgeber schlesischer Kantionale hat im weitesten und gründlichsten Maße seinen Vorgänger und Vorläufer als Quelle ausgeschöpft und nachgeahmt. Georg Schlag hat z. B. in sein Kantional gar keine neuen Gesichtspunkte hineingebracht. Bei ihm lassen sich die Lieder oft in dersel- 
ben Reihenfolge, das gleiche Lied auf der gleichen Seite, wie im Rohrmannschen Kantional nachweisen. Ähnliches gilt für Robert Fiedler als Herausgeber des Bockshammerschen Kantionals. Druckfehler und grammatische Sprachentstellungen wurden mitunter sogar durch mehrere Auflagen geschleppt.

Neben der von Danzig und Thorn beeinflupten schlesischen Kantionallinie hat Schlesien noch zwei, von jener Linie unabhängige, zu verzeichnen. Ich möchte sie Nebenlinien nennen, weil sie in Schlesien keine größere Verbreitung fanden. Die eine Linie stellt den. Kantionaldruck von Chuć - Hennig, die andere das Kantional mit Daniel Naglo als Verfasser dar. Diese Gesangbücher waren von der sogenannten Hauptlinie nicht beeinflußt. Im Kantional von 1804 lassen sich neben einer originellen Liedergliederung viele Selbständigkeiten feststellen. Leider sind in den Liedern vielfach unmögliche Sprachwendungen, die wohl sämtlich auf Chuc selbst zurückgehen, anzutreffen. Besonders unter den Liedern von der "Wstrzemięźliwość i mierność" und "Czystość przeciwna lubieżności" trifft man manchen Ausdruck an, der dem Charakter eines geistlichen Liedes nicht entsprechen kann. Aber dennoch ist dieses Gesangbuch das liederreichste in Schlesien, und man kann annehmen, da $\beta$ seine Sprache in Schlesien vom Volke eher als die anderer Kantionale verstanden wurde.

Eine selbstständige Stellung nimmt das von Pfarrer Daniel Naglo verfaßte Gesangbuch unter den schlesischen Kantionaldrucken ein. Mit seinen 377 Liedern, die Ubersetzungen aus dem deutschen Breslauer Gesangbuch von 1775 sind, konnte dieses Kantional keine größere Volkstümlichkeit in Schlesien erlangen. Es lag vielleicht daran, da $\beta$ es, herausgegeben im Jahre 1776, in den Schatten des Bockshammerschen Gesangbuches von 1776 fiel. 


\section{A N M E R K U N G E N}

1) Zur Veranschaulichung über Anderungen zu Recht oder Unrecht in evangelischen Kirchenliedern seien einige Beispiele aus dem Buchlein "Ist es recht die alten Kirchengesänge zu ändern?" Dessau 1782. van einem Liederfreunde, angeführt. In dem Liede "Nun komm der Heiden Heiland" stand eigentlich am Schlup "Lob sey Gott dem Vater thon". Thon hei $\beta^{t}$ hier soviel wie getan. $\mathrm{Da}$ dieses thon in

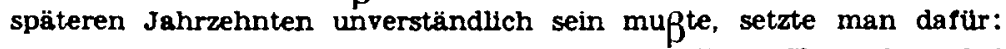
"Lob sey Gott im höchsten Thron". Der Prediger Klepperbein bei der lutherischen Gemeinde in Amsterdam fand den Ausdruck gemetn im Liede "Nun freut euch, lieben Christen, gemein" unverständlich und lie $\beta$ dafür "Nun freut euch, liebe Christen-Gemein" drucken. In dem gleichen Liede hei $\beta^{t}$ es bei Luther am Ende: "Das la $\beta$ ich dir zur Letze". Die neueren Liedersammlungen tragen meist diese Anderung: "Das la $\beta$ ich dir zulezte". Letze (vgl. Letzatrunk, Letzworte, Letz\&ru $\beta=$ Valedictio) hei $\beta$ t aber Abschled, letzen $=A b-$ schied nehmen, was wieder die falsche Verbesserung des Wortes in den Gesangbuichern veranschaulicht. Manches Gesangbuch kam dem Sinn näher mit dem Druck: "Das sey mein Abschieds Segen". Im runften Vers des Liedes "Gelobet seyst du Jesu Christ" hei $\beta^{t}$ es: "Der Sohn des Vaters, Gott von Art, ein Gast in der Werlet ward". Für das allmählich unverständlich gewordene Wort Werlet hat man in vielen Gesangbüchern das neuere Welt gesetat. Hier ist die Xnderung eine Modernisierung der Wortform, die dann die Einfiligung von hie aus metrischen Grlinden nötig machte.

Zu dem Liede: "Erhalt uns Herr bei deinem Wort" von Martin Luther hat Justus Jonas, der Freund Luthers, im Hinblick auf das Konzil von Trient einen vierten und füften Vers geschrieben. Einen sechsten Vers schrieb dazu die Kurfürstin Sibylla, Gemahlin des Kurfursten Johann Friedrich von Sachsen, aus Anla $\beta$ der Gefangenschaft ihres Mannes:

"Ach Herr la $\mathrm{dir}$ befohien sein

Unsern Landesherrn, den Diener dein;

Im festen Glauben ihn erhalt

Und rett ihn aus der Feind Gewalt".

Nach der Freilassung des Kurfürsten wurde der Vers abgeändert:

"Und la $\beta$ dir Herr befohlen sein.

Unser Kirchen, die Kinder dein,

Im wahren Glauben uns erhalt

Und rett' uns vor der Feind' Gewalt".

(8. Wangemann. Kurze Geschichte des Ev. Klrchenliedes $\mathbf{5}$. 122). 
Im schlesischen Gesangbuch, zu Breslau und Liegnitz im Jahre 1711 gedruckt, wird in der Vorrede uber viele Lieder geklagt, die man wegen ihrer Dunkelheit fortlassen mü $\beta$ te: so die Lieder: "Nun komm der Heiden Helland" und "Da Jesus an dem Creuze stund".

Bei den verschiedensten Drucklegungen hat man viele Hieder ganz umgearbeitet. In Gesangbüchern findet man das Ifed: "Da Jesus an dem Creuze stund" oft in doppelter Fassung. "Da Jesus an dem Creuzes Stamm" hei $\beta$ t vielfach die Varlante. Da Jesus am Kreuze nicht gestanden, sondern gehangen ist, wird der umgearbelteten Liedform vor der Originalfassung häufig der Vorzug gegeben. Eine weitgehende Variante besitzt der Gesang: "Jesu deine tiefen Wunden" mit der Fassung "Jesu deine hell'gen Wunden" als Gebet. Fine verschiedene tbersetzung aus dem Lateinischen zeigt das Abendlied "Christe, der du bist Tag und Licht" und "Christe, der du bist der helle Tag". Davon glbt es noch eine dritte Variante mit "Christe, der du bist Licht und Tag, gib, daß dein Licht die Nacht verjag".

2) Geb. zu Gröben bei Jena 1649, gest. 1708; Gymnasium zu Welmar, studierte in Jena, von 1680 Konrektor des Berlinschen Gymnasiums, später Rektor (s. Allgemeine Deutsche Biographie, Bd. 29, S. 25).

3) Geb. 1530 oder 1531 zu Frankfurt a. O., gest. 1599 (s. Allgemeine Deutsche Biographie, Bd. 28, S. 640).

4) 8. Wackernagel, a. a. O., Bd. 4, S. 344 f. und Mützell, a. a. O., S. 680 und S. 1023.

5) Als "zwłacza sie dzień sądny ostateczny" - der Tag des jtangsten Gerichts verzoegert sich - ist es in Schlesien in dieser Form nicht gebraeuchlich gewesen.

6) Erklaert Bockshammer mit "WRechwiadomosć Boźa przez ksiegi pisane sie rozumie".

7) Erklärung bel Bockshammer: "z martwych".

8) Druckfehler für wielcy.

9) Richtig dźledśictwo.

10) Hat als Erkaerung t.1. Nieshußnie.

11) In der fünfbändigen Ausgabe von Wackernagel, Das deutsche Kirchenlied, befindet sich der gleiche Text im 3. Bd. auf S. 232.

12) SG 1718 hat das Lied auf S. 203 unter "Advents-Lieder" aufgezeichnet. Es trägt hier die Melodieangaben "Gottes Sohn ist kommen" und "O Herr nun im friede". Michael Wei $\beta$ e wird auch hier als Verfasser genannt.

13) Kühnast, a. a. O., Deutsche Kirchenlieder in Polen, 2. Abtellung, S. 8.

14) K 1776, S. 81 f: ludzi naśladuiqc erklaert Bockshammer mit ztych obyczaiono ludzi.

15) 8. D. Martin Luthers Werke, Kritische Gesamtausgabe, Bd. 35, \$. 152 If. (1923), Wackernagel, Das deutsche Kirchenlied, Bd. 3, S. 17 (1870). 
16) Bel Oloff, Polnische Liedergeschichte..., s. 495, hei $\beta^{t}$ der Ubersetzer des Liedes, Andreas Ronczkowius.

17) ebenda.

18) a. a. O., S. 8, 3. Abteilung.

19) A. K. kennzeichnet Andreas Kotenius als Verfasser.

20) K 1776, S. 497 hat zu do chorqgwie die Erlaeuterung: jako się zolnierze do chorągwie zbleraią.

21) K 1776 S. 497 erklaert Bockshammer mit "opowiadanie", was den Eindruck verstaerkt, da $\beta$ dieses Fremdwort für die einfachen Glaeubigen z.Z. Bockshammers ein unverstaendlicher Begriff war. Mandat von lat. mandatum nicht von mandamus, wie Linde im "Słownik Jẹzyka Polskiego" Lemberg 1857. Bd. 3. S. 39 angibt. Die Erlaeuterung opowiadanie für mandat trifft nicht ganz den sinn des Wortes. Besser ist die Erklaerung, die das "Warschauer Woerterbuch", Warschau 1902 Bd. 2 S. 871 gibt: pozew, rozkaz, nakaz, przykaz, wola, polecenie, postanowienie, wyrok, upoważnienie. Seltsamerweise haben alle neueren Gesangbücher diesen Ausdruck im Text beibehalten.

22) Gen. Plur. von wolośc, bedeutet "własność", "posiadłośce", "dziedzictwo", "posesja". Für Schlesien dürfte wlosć zu geschraubt geklungen haben und unverstaendlich gewesen sein.

23) Wenn Johann Kutsch die Aenderung von izraelski in chrzescianiski vornahm, dann mu $R$ inn ein bestimmter Gedanke dazu bewogen haben, vielleicht seine Abneigung gegen das Judentum. Dieselbe Aenderung nahm Kutsch auch in dem Liede 'Nun preiset alle Gottes Barmherzigkeit", "Chwalcie spolecznie milosierdzie Pańskie" vor. Uberhaupt hat er in seinem ganzen Kantional das Wort "Izrael", "izraelski" durchweg ausgemerzt und durch "Chrzescianie" bezw. "chrzescianski" ersetzt.

24) Geb. 1628, gest. 1693. Er war zu Hayn Im Furstentum Liegnitz, dann zu Königsberg und Thorn als Kantor tätig.

25) s. Kühnast, a. a. O., S. 19 (1858) und Oloff, a. a. O., S. 22 und 305.

26) Nach Kühnast, ebenda, soll das Lied bereits in Hentschels Hauspostille und in den Breslauer Pieśni von 1717 abgedruckt sein. In den schlesischen Kantionalen vor 1773 ist das Lied jedoch nicht zu finden.

27) Erklaert Bockshammer in $K$ 1776, $S .168$ mit: niech mie to ciepy żes ty za mie clerpial.

28) Beibehaltung des deutschen "Stich". Im Mittelalter kam es als deutsches Lehnwort ins Polnische. Diesen Germanismus haben alle polnischen Gesangbuicher in Schlesien in diesem Liede bis in die neuere Zeit beibehalten.

29) K 1790 , S. 168 hat den Druckfehler beseitigt und schreibt "zwyciezco"; erst K 1861 bringt das Wort richtig mit Nasalvokal.

30) Prof. d. Theol., Stadtpfarrer und Superintendent in Wittemberg Geb. 1511, gest. 1569 . 
31) s. Wackernagel, a. a. O., S. 380.

32) Vgl. Wackernagel, ebenda.

33) Er stammte aus dem Kulmer Kreise, von 1584 ab, Prediger in Thorn, gest. 1606. Er hat mehrere deutsche Lieder ins Polnische übersetzt. Vier seiner Lieder nahm Artomius in sein Kantional auf. (Lit.: Wielks Encyklopedya Powszechna Ilustrowana, T. 23, S. 945 (Warschau 1899).

34) K 1776, S. 457 hat die Erklaerung Bockshammers zaprawde.

35) a. a. O., S. 298.

36) A. Brückner betrachtet die schlesischen Kantionale als eigene Gruppe (s. Artikel über "Kancionaly" in "Encyklopedja Staropolska" Tom A-M, S. 518 ff.). 